\title{
A Meta-analysis of Relationships between Organizational Characteristics and IT Innovation Adoption in Organizations
}

\author{
Mumtaz Abdul Hameed, Steve Counsell and Stephen Swift \\ Department of Information Systems and Computing, Brunel University, \\ Uxbridge, Middlesex UB8 3PH, UK \\ mumtaz.abdulhameed@brunel.ac.uk
}

\begin{abstract}
.
Adoption of Information Technology (IT) in organizations is influenced by a range of factors in the context of technology, organization, environment and individuals. Amongst others, the IT literature has identified several organizational factors that either facilitates or hinders innovation adoption in organizations. Studies examining the factors influencing IT adoption have produced inconsistent and contradictory outcomes. We performed a meta-analysis of ten organizational factors to determine the relative impact and the strength of these attributes on IT adoption. The study aggregated the findings of past research to evaluate the magnitude and the direction of the relationship between organizational factors and IT innovation adoption. Results showed organizational readiness to be the most significant attribute. We also found a moderately significant relationship between IT adoption and Information Systems (IS) department size. The study found weak significance with IS infrastructure, top management support, IT expertise, resources and organizational size. Formalization, centralization and product champion were found to be insignificant attributes for IT adoption. The study also examined stage of innovation, type of innovation, type of organization and size of organization as four moderator conditions that affect the relationship between organizational variables and IT adoption.
\end{abstract}

Keywords: IT innovation adoption; meta-analysis; moderating effect.

\section{Introduction}

An innovation can be thought as an idea, a product, a program or a technology that is new to the adopting unit $[13,69,96]$. The adoption of innovation is a process that results in the introduction and use of a product, process or practice that is new to the adopting organization [21,41]. Innovation has been studied in a variety of academic disciplines and at different levels of analysis [20] and innovation research has been conducted in disciplines such as anthropology, sociology, communication, education, economics, management, organizational studies, Information Technology (IT) as well as others [26].

IT enables organizations to be more efficient and to gain a competitive advantage; it has significant impact on organizational operation and it is generally believed to provide a greater marketing opportunity and increased competitiveness. IT adoption presents potential adopters with new means of solving problem and exploiting opportunities [4]. IT provides opportunities for exploring knowledge, systems and resources in the market place to improve products, services and technologies [21]. In the last two decades, Information Systems (IS) researchers have focused particularly on studying innovation in the adoption of IT [6] and substantial amounts of research has been conducted in the adoption of IT both in an organizational and individual context [19, 32, 46, 81]. Actual adoption of innovation in an organization can be initiated by either a response to a change in the environmental conditions in which it operates or at the point when innovation becomes a requirement for its routine organizational operation. Equally, the adoption of an innovation can be prompted by a decision of 
management in the belief that it will improve organizational performance [81]. An organization which possesses the financial and technical resources, a stronger motivation to acquire the innovation due to the realization of its benefits and an optimistic attitude by management is more likely to adopt innovation [25].

Despite the large amount of literature examining factors that facilitate or inhibit IT adoption, IT literature falls short in understanding and validating a set of characteristics that would influence the adoption of an innovation. Studies addressing innovation adoption have often yielded inconsistent and conflicting findings. Wolfe [95] indicates that the most consistent theme found in the organizational innovation literature is inconsistency of study findings. Rye and Kimberly [73] further support this claim by stating that the inconsistency in research findings has been a defining theme in adoption and diffusion research. This feature of past research makes it almost impossible to draw firm conclusions on the effects of different factors influencing IT adoption. In fact, a consistent set of attributes for innovation adoption has yet to be recognized.

Identifying the factors that determine the adoption of IT is fundamental for ensuring successful adoption and implementation of effective procedures. This study aims to fill the knowledge gap in IS literature by validating the important determinants of organizational IT innovation adoption in terms of organizational context. The study attempts to uncover important organizational factors affecting IT adoption as well as quantify their relative importance. It achieves this by exploring the results of past studies on organizational characteristics influencing IT adoption. Variations in past empirical findings for different innovation adoption determinants make its practical application inadequate. Damanpour [16] suggests that in the absence of a thorough comparison of existing findings, it is not appropriate to deduce conclusions of generality or inconsistency of research results. Aggregating existing literature allows the validation of the existing findings and clarification of the inconsistency that might exist amongst primary studies [42].

The key research question that motivates our study is "What are the key organizational factors that guide successful adoption and implementation of IT innovation in organizations". To better understand these determinants, we developed a conceptual model (based on the IT literature) relating to the process of IT innovation adoption and organizational factors affecting IT adoption. The contribution of the study is to better understand the major organizational determinants facilitating a successful IT adoption process. IT literature rarely examines the effect of organizational factors in different demographic conditions. Through past empirical studies, our findings enhanced knowledge of the effect of different organizational factors on the specific contexts under which IT is adopted.

\section{Background}

\subsection{IT innovation adoption}

Research on innovation adoption began during 1940s; however, the IS community only started to focus on IT innovation and diffusion research from the mid-1980s onwards. During the past two decades, researchers and practitioners have focused studies of IT adoption at both the organizational and individual levels. Organizational level studies examine the process of adoption and diffusion of IT in the context of the adopting organization [25, 59]. IT has become a means of improving an organization's operational and strategic practices and can leverage the efficiency and effectiveness of various organizations [32].

Researchers have also examined a range of factors influencing the adoption of IT. Four major categories commonly identified in the literature are technological, organizational, environmental and individual $[7,30,86]$. In a technological context, researchers have named perceived benefits, cost, complexity and compatibility as key determinants. For organizational characteristics, the size of the 
organization, support from top management, existing resources and IT expertise within the organization are all relevant $[38,64]$. Competitive pressure, demands from their trading partners and customers, support from government and environmental uncertainty have also been studied as environmental factors $[11,65]$. In terms of individual aspects, researchers have examined Chief Executive Officer (CEO) IT knowledge, CEO attitude towards IT and innovativeness of the CEO, amongst others [20,87].

\subsection{Organizational characteristics and IT innovation adoption}

Herein, we focus on the association between organizational characteristics and IT adoption. The IT literature identifies several organizational factors that influence innovation adoption. Table 1 illustrates these with salient references.

\begin{tabular}{lrlrr}
\hline Organizational Characteristics & References & & Organizational Characteristics & References \\
\cline { 1 - 2 } \cline { 5 - 5 } Top Management Support & $23,64,85$ & & Organizational Size & $19,37,98$ \\
IT expertise & $38,44,86$ & & IS Department Size & $32,46,59$ \\
Product Champion & $7,63,74$ & & Organization Readiness & $35,51,52$ \\
Formalization & $11,23,28$ & & Centralization & $32,46,59$ \\
IS Infrastructure & $11,40,63$ & & Resources & $19,46,57$ \\
IS Investment & 11,91 & & Information Intensity & 28,54 \\
Training & 3,83 & & Motivation & 76,77 \\
Culture & 1,76 & & Specialization & 25,81 \\
Number of Business lines & 37 & & Information sharing culture & 85 \\
Number of Customers & 37 & & Openness & 46 \\
Organizational Complexity & 20 & & Normencouraging & 46 \\
Image & 40 & & Number of competitors & 37 \\
Expansion & 46 & & Satisfaction with Exisitng System \\
Managerial Obstruction & 98 & Degree of Integration & 8 \\
Earliness of Adoption & 23 & Perceived Barrier & 98 \\
\hline
\end{tabular}

Table 1: Organizational characteristics considered in literature and some references

Premkumar and Roberts [64] considered top management support, organizational size and IT expertise as three organizational variables in their study on United States (US) small businesses. Thong [86] studied, amongst others, business size, employee IS knowledge and information intensity to address organizational factors facilitating IT adoption and implementation in Singaporean small businesses. Eder and Igbaria [23] in research on intranet diffusion and infusion in organizations examined top management support, organizational size, IT infrastructure, organizational structure and IS structure. Lai and Guynes [46] studied the influence of organizational characteristics on Integrated Services Digital Network (ISDN) adoption decisions and verified openness, norms encouraging change, slack resources, size, centralization, formalization, complexity, expansion and control as relevant characteristics. Iacovou et al. [35] considered organizational readiness as one of the factors that influenced Electronic Data Interchange (EDI) adoption. Tsao et al. [91] assessed top management support, organizational readiness, IT investment and staff resistance with respect to organizational perspective in identifying success factors of business-to-business e-commerce adoption in Taiwanese companies. Similarly, Teo and Ranganathan [84] in discriminating adopters and non-adopters of business-to-business e-commerce in Singaporean firms considered the demographic profile of the organization, presence of a champion, formal plan, years of e-commerce experience, expected and 
realised benefits from e-commerce, management support and risk orientation as organizational factors.

Among the organizational characteristics considered in the literature, some characteristics have been considered consistently. To identify the key organizational determinants influencing the adoption and implementation of IT, a study needs to examine the magnitude and strength of factors most frequently considered.

\subsection{Meta-analysis}

To investigate a particular topic, researchers often accumulate knowledge across studies. The findings of a number of related studies can be aggregated to find an overall outcome. The information collected can be qualitative in nature but, more often, is quantitative and traditional methods of aggregating studies have focused on combining statistical significance testing [34]. The reviewed studies herein performed tests of significance to verify factors affecting the adoption of IT. Variances in the interpretation of these test results also arise [34].

Meta-analysis is a statistical technique for amalgamating, summarising, and reviewing previous quantitative research and has been used to find the relative impact of independent variables as well as the strength of relationship between variables [29]. Meta-analysis refers to a series of procedures for quantitatively accumulating 'effect sizes' across studies and analyzing research to reach an overall conclusion. Effect sizes can be expressed in similar forms as correlation coefficients [12]. The most commonly followed meta-analysis procedures to compute the overall measure of relationship between variables were described by Glass et al. [29] and by Hunter et al. [34]. The meta-analysis procedure described by Hunter et al. [34] also includes methods to correct sampling errors, errors of measurement and range of variance [17]. In this study, we thus adopt the meta-analytic steps described by Hunter et al. [34] to analyze the correlation results of studies on organizational factors affecting the adoption of IT.

\subsection{Moderators for relationships between organizational characteristics and IT adoption}

The study we present reviewed past literature on IT adoption and, specifically, organizational factors influencing the adoption of IT. The review of studies based on factors affecting the adoption of IT showed mixed results in its findings. IT adoption research conducted in different surroundings, sectors, groups and demographic conditions often produce varying results [17]. Using meta-analysis procedures, it becomes possible to examine the effects of these conditions commonly known as moderators. Examining the effect of these conditions on the relationship between organizational factor and IT adoption introduces a third variable into the analysis.

We examined the effect of four moderator categories on the relationship between organizational factors and IT adoption. They were stage of innovation, type of innovation, type of organization and size of organization. We chose these four factors since these were most commonly quoted statistics in the individual studies reviewed. In the next four subsections, we describe each.

\subsubsection{Stage of Innovation Adoption}

The adoption of innovation in organizations can be described as a stage-based process and has been divided into a variety of phases. Adoption of innovation navigates a sequence of activities from the decision-making phase to the stage where the actual innovation is put into use and subsequently used for organizational processes [17]. Kwon and Zmud [45] describe adoption and diffusion starting with initiation and progressing through adoption, adaptation, acceptance, routinization and infusion. 
Rogers [70] describes three stages and refers to them as initiation, adoption-decision and implementation. The three phases of initiation, adoption-decision and implementation are often referred as pre-adoption, adoption-decision and post-adoption in the IS literature.

The pre-adoption stage identifies the need for a new innovation, gathering knowledge of the solution to replace the existing and proposal of innovation for adoption [71]. Adoption-decision consists of evaluating planned technology, making a decision to accept the innovation suggested and allocation of necessary resources to facilitate an environment for its implementation [53]. Finally, the postadoption stage includes the acquisition of innovation, acceptance by the users and continued use of the innovation for the organizational operations [71].

The different stages described by other researchers falls into the activities of pre-adoption, adoptiondecision and post-adoption phases. For this reason, we used sub-stages of initiation (pre-adoption), adoption-decision and implementation (post-adoption) to distinguish the phases in IT adoption. To define the stage of innovation, the study divides the literature into studies that were conducted for a) initiation, b) adoption-decision c) implementation and finally, d) those that were conducted for all stages of innovation.

\subsubsection{Type of innovation}

Innovation is a complex construct, studied from multiple perspectives at different levels of analysis [19]. Researchers have classified innovation into further groups to study adoption behaviour and antecedents of IT adoption. Zmud [99] classified innovation into product or process, while Damanpour [17] groups the innovation as either product versus process and technical versus administrative.

Research has shown different adoption patterns for the adoption of product and process innovation $[18,92]$. Different factors influence the adoption of product and process innovation and the degree to which that innovation impacts organizational performance [89]. Damanpour and Gopalakrishnan [18] highlighted distinctions in terms of organizational skills required for the adoption of product and process innovation. Product innovation is defined as the introduction of a new product or service and process innovation the introduction of a new system or new method that changes the operational process or processes.

\subsubsection{Type of Organization}

IT innovation has a huge impact in leveraging productivity and efficiency of any organization. Organizations adopt IT to enhance the scope of their products and services. Within organizations, innovation activities involve adding new services, improving production capability, expanding existing processes or improving the service delivery process. Almost all industries, public or government utilize IT to improve efficiency and effectiveness. Most IT research discusses manufacturing and service as the two main industry types for evaluating the impact of IT in organizations. Damanpour [17] identified organization type as manufacturing or service and profit or not-for-profit. Researchers have conducted studies based only on manufacturing industry or service industry.

According to the definition of Standard Industry Classification (SIC) - UK, manufacturing organizations are engaged in the mechanical or chemical transformation of materials or substances into new products (automotive, chemical, food production, household items, medical etc.) while service industries are engaged in providing a wide variety of services for individuals, businesses and government establishments and other organizations (financial institutions, travel, healthcare, merchandising, transport, telecommunication, etc). Nie and Kollogg [56] identified unique characteristics of the organizations of the service sector such as customer participation, intangibility, 
heterogeneity and labour intensity compared to manufacturing organizations. These differences are likely to influence IT adoption patterns within these two organizational groups. Due to these differences, factors influencing the usage of IT in manufacturing sector are different from the service sector [9]. The study therefore makes a distinction between manufacturing and services organizations.

\subsubsection{Size of Organization}

Innovation adoption research tends to target its studies on the size of the organization. Researchers usually make a distinction between large and small organizations in conducting their empirical studies. Large and small organizations possess certain distinct characteristics of their own and are fundamentally different in a number of aspects [86]. The challenges they face, the opportunities and management issues they deal are incomparable. Small businesses pose a greater risk in IT adoption due to the lack of technical and financial resources, inadequate IT infrastructure and a short-range management perspective [80]. IT innovation adoption that influences larger organizational contexts may not be applied to small businesses. In the analysis presented, we therefore use size of organization as a moderating condition and divide the literature into a) large organizations, b) studies intended for small organizations and SMEs, and c) studies conducted for mixed-size organizations.

\section{Research Model}

In this study, it is proposed that a number of organizational factors influence different stages of IT adoption in organizations. A list of organizational factors considered in IT literature is shown in Table 1. Section 2.4.1 also describes the stages of innovation adoption as initiation, adoption-decision and implementation. Based on organizational factors identified in the literature and the stages of innovation adoption, we propose a research model for the study. Figure 1 presents the conceptual model for the relationship between organizational factors influencing adoption and implementation of IT in organizations.

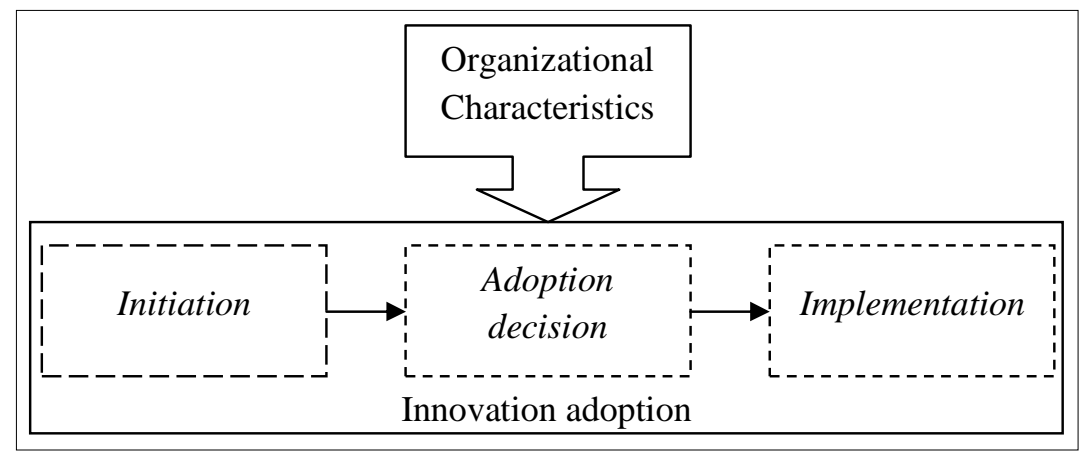

Figure 1: Conceptual model for the organizational characteristic influencing IT adoption in organizations

\section{Research Method}

Meta-analysis is a quantitative method for evaluating the results of several studies to obtain an average outcome [72]. Using a meta-analysis, the study identifies the significance of the relationship between these individual organizational characteristics and IT adoption. The aim of using a metaanalysis procedure for the study presented was to evaluate findings of past studies examining organizational attributes affecting IT adoption; these are then aggregated to obtain overall conclusions regarding the magnitude and direction of the relationships. A meta-analysis allows examination of the 
effects of different research conditions or 'moderators' influencing the relationship between organization determinants and IT innovation adoption. We split the studies into different categories of moderators; one example of a moderator would be 'type of innovation' separated into two categories of 'product innovation' and 'process innovation', to investigate the effect of these conditions on IT adoption.

\subsection{Study selection}

We reviewed ninety-two relevant published studies on IT adoption. We searched IS Journals and Google Scholar with the key words 'innovation', 'adoption', 'diffusion', 'infusion', 'integration', 'implementation', 'information technology', 'information system' and 'IT usage' to obtain relevant articles. The studies assessed were from 1990 to 2009. The study selection criteria for the metaanalysis were:

(a) It was an empirical study on IT innovation adoption.

(b) The study examined the organizational context of adoption of innovation in its empirical evaluation.

(c) The dependent variables included initiation, adoption-decision (adoption) or implementation.

Following the above criteria, we obtained a total of fifty-nine empirical studies for the analysis. Among these fifty-nine studies extracted, forty-one studies were published between the years 2000 to 2009 and eighteen between the years 1990 to 1999. As some of studies considered more than one type of innovation and different stages of innovation adoption, a total of ninety-seven IT innovation adoption relationships were obtained.

The studies used different statistical treatment or analysis. Thirty-one used correlation in their analysis; five studies were based on regression techniques while five used discriminant analysis. Descriptive studies were conducted by seven of these studies and eleven studies employed other forms of statistical evaluation. Since the meta-analysis procedure by Hunter et al. [34] utilizes values of correlation coefficient, we selected studies that used correlation techniques for our meta-analysis.

We gathered all organizational factors considered in the fifty-nine studies. To perform the metaanalysis, we filtered the studies that provided correlation coefficients for the relationship between organizational factors and IT adoption. At least two correlation results for each organizational factor were required to carry out the analytical procedures. Studies provided the required data for only ten organizational factors to perform the meta-analysis.

Table 2 details the ten organizational variables considered in the study and the expected association with IT innovation adoption based on the literature. A positive association 'facilitates' IT adoption and a negative association 'inhibits' IT adoption.

\subsection{Coding}

Before conducting the analysis, we coded dependent and independent variables. Adoption of IT was considered the dependent variable and the organizational factors influencing the adoption of IT, the independent variable. Studies that included more than one innovation were coded separately and treated as individual data sets. The independent variables were organizational characteristics that influenced initiation, adoption-decision and implementation of an IT innovation.

The reviewed studies used different names to describe some of the independent variables. Hence, in coding the independent variable, we refer to the context in which the variables were used in the 
individual studies. Table 2 also shows the different names used in the studies to refer to the independent variables.

\begin{tabular}{|c|c|c|c|}
\hline Independent variables & Description & Other names based on the context & $\begin{array}{c}\text { Expected } \\
\text { association } \\
\end{array}$ \\
\hline Organizational Size & $\begin{array}{l}\text { Number of employees within the organization or total sales } \\
\text { revenue }\end{array}$ & Business size & Positive \\
\hline IT Expertise & $\begin{array}{l}\text { Prior experience of IT in term knowledge of individuals and } \\
\text { within the organization }\end{array}$ & $\begin{array}{l}\text { Technology competence, Technical capability, IT } \\
\text { knowledge, IT sophistication, Employees IT knowledge, } \\
\text { Existence of IS department, Knowledge of IT in company, IT } \\
\text { maturity, Education }\end{array}$ & Positive \\
\hline Top Management Support & $\begin{array}{l}\text { Extent of commitment of resource and support from the top } \\
\text { management to the innovation }\end{array}$ & CEO support & Positive \\
\hline Resources & $\begin{array}{l}\text { Amount of financial, technical and human resources for the } \\
\text { adoption process }\end{array}$ & Economic Health & Positive \\
\hline IS Department Size & $\begin{array}{l}\text { Existing IT function and dedicate IT personal within the } \\
\text { organization }\end{array}$ & IT function size & Positive \\
\hline IS Infrastructure & $\begin{array}{l}\text { Availability of IT resources within the organization for the } \\
\text { adoption }\end{array}$ & IT resources, IS sophistication & Positive \\
\hline Formalization & $\begin{array}{l}\text { The extent of the use of rules and formal procedures within } \\
\text { the organization }\end{array}$ & $\begin{array}{l}\text { IS structure, Technology strategy, Organizational objective } \\
\text { consensus }\end{array}$ & Negative \\
\hline Centralization & Level of centralization of decision making in organization & Organizational structure, Decision making pattern & Negative \\
\hline Organizational Readiness & $\begin{array}{l}\text { Level of awareness, resources, commitment and governance } \\
\text { for adoption }\end{array}$ & Technical competence, IT maturity, Education & Positive \\
\hline Product Champion & $\begin{array}{l}\text { Existence of high level individual to promote the innovation } \\
\text { within the organization. }\end{array}$ & Innovation champion, Technology leader & Positive \\
\hline
\end{tabular}

Table 2: Ten organization characteristics and its expected relationship with IT adoption

In addition, information on four moderators was also coded for each study. Four moderators and their categories were defined as a) stage of innovation: initiation, adoption, implementation, mixed; b) type of innovation: product, process, mixed; c) type of organization: manufacturing, service, mixed; and d) size of organization: large, small and medium enterprise (SMEs), mixed.

The Appendix shows individual studies considered in the analysis. It shows the sample size, coding of moderators and the result of test of significance with correlation values.

\subsection{Significance test and correlation coefficient}

The results of the relationship between organizational characteristics and IT adoption were evaluated in terms of test of significance. Statistical significance denotes the probability that a relationship exists between individual organizational characteristics and IT adoption. The test of significance verifies that the observed value differs from the theorized value and statistical significance is determined by effect size and sample size [72]. Hence, studies with same effect size could have different statistical significance and consequently aggregating test of significance could produce a confusing outcome [34].

All fifty-nine empirical studies considered in this analysis provide significant test results for different independent variables. We analyzed the aggregated result of test of significance to verify the importance of different organizational factors in IT adoption. Additionally, the aggregated significant test result shows the inconsistency across the studies of IT adoption.

Values of the correlation coefficient range between -1 and +1 ; values that fall 0 to -1 indicate a negative relationship and values between 0 to +1 indicates a positive relationship. A correlation coefficient of 0 demonstrates that the variable has no relationship. Correlation coefficients do not have a precise interpretation but are often classified as weakly, moderately or strongly significant. Cramer [15] classifies correlation coefficients between 0 to \pm 0.05 - no significance, \pm 0.06 to \pm 0.10 - weak significance, \pm 0.11 to \pm 0.15 - moderate significance and \pm 0.16 to \pm 1.0 strong significance. DeVaus [22] classifies correlation as 0 to \pm 0.09 - insignificance, \pm 0.10 to \pm 0.29 - weak significance, \pm 0.30 to 
\pm 0.49 - moderate significance, \pm 0.5 to \pm 0.69 - strong significance, \pm 0.70 to \pm 0.89 - very strong significance and \pm 0.9 to \pm 1.0 near perfect. In this study, we adopt the classification of DeVaus [22].

\subsection{Meta analysis procedure}

A sequence of procedures was used to aggregate statistical results from independent studies to find a more accurate estimation. The procedures involved accumulating effect sizes across studies, combining them and evaluating to obtain an average effect size. We applied the accumulation procedures described in Hunter et al. [34], to derive the overall results of the studies. For the calculation, we used studies that performed correlation analysis for each of the independent variables. The statistic extracted from the studies was the correlation coefficient and we performed five basic steps in our analysis.

1. Compute the mean correlation coefficient for the studies.

2. Calculate the variance across studies; we call this the 'observed variance'.

3. Calculate the effect of variance by the sampling error; we will call this 'sampling error variance'.

4. Compute the percentage of observed variance explained by sampling error variance.

5. Compute $95 \%$ confidence interval using mean correlation.

For step 1, we calculated the mean population correlation by converting each of the observed correlation values into population correlation and averaging the values. This was done to calculate a weighted mean correlation for each individual observed estimate by their corresponding sample size. To calculate the mean population correlation, we multiplied each correlation coefficient by its corresponding sample size and divided by total sample size. This frequency weighted average gives a greater weight to results obtained from larger samples. Averaging population correlations across studies eliminates the effect of sampling error [34]. The correlation coefficient is not normally distributed and its variance is not constant. 'Fisher's z-Transformation' is often used to normalize the distribution and stabilize potential variance. We calculated the Fisher's z-transformation from the mean correlation values and these $\mathrm{z}$-values were used to compute confidence internals.

For step 2, the observed variance across studies was calculated. The observed variance is explained by variations due to population correlation and sample correlations produced by sampling error. The sampling error adds to the variance of correlations across studies [34]. Variation due to population correlation can be obtained by eliminating variation due to sampling error.

To eliminate sampling error due to variance, in step 3, we first derived the effect of variance by sampling error. The variance due to sampling error is calculated using the mean population correlation and average sample size. By subtracting sampling error variance from the variance in the sample correlation (observed variance), the variance due to population correlation can be obtained. To account for moderator effect of the individual organizational attributes, step $\mathbf{4}$ calculated the percentage of observed variance explained by sampling error variance. If the percentage of the observed variation is mostly due to sampling error variance, a moderator effect can be assumed as minimal. However, if the percentage obtained in step 4 is not sufficiently high, a substantial amount of observed variance is due to variation in population correlations. This indicates that the study requires the examination of moderator effect. Peters et al. [60] has suggested that the moderator effect should be performed if the sampling error variance is less than $60 \%$ of the observed variance. For every organizational attribute that showed a sampling error variance of less than $60 \%$ of observed variance, we introduced four moderating conditions and performed a meta-analysis. 
Finally, to find the significance of the independent variable in IT adoption, we computed a $95 \%$ confidence interval (step 5) using the values obtained from z-transformation of mean correlation. The confidence intervals cannot be computed directly using mean correlation coefficient due to variance in sample size of individual studies. Use of Fisher's z-transformation value makes it possible to calculate these values indirectly. The relationship between independent variable and IT adoption was regarded as statistically significant if the confidence interval did not include zero. If the $95 \%$ confidence interval is in the range 0 to 1 , it indicates a positive association; if the interval falls between 0 to -1 , it implies a negative association.

\subsubsection{Meta analysis procedure and moderators}

The review of studies based on factors affecting the adoption of IT showed mixed results in its findings. It was therefore necessary to explore different conditions or moderators that may have influenced the relationship between organizational factor and IT adoptions. A moderator is therefore a different research context (e.g., size of organization, type of organization) that affects the strength and direction of the relationship between organizational characteristics and IT adoption.

To examine the effect of the moderator, studies were divided into subgroups of these moderator conditions and meta-analyses were undertaken for each subgroup to verify the strength of the relationship between organizational factors and IT adoption in that category.

\section{Results}

\subsection{Significant test results}

From the fifty-nine studies, a total set of ninety-seven innovation adoption relationships with organizational factors were assessed. Six relationships considered the initiation stage of adoption, fifty-eight relationships examined adoption-decision stage, twenty-seven verified relationships at the implementation stage and six assessed mixed stages of innovation adoption.

Table 3 shows the aggregated significance test results for all the independent variables considered in this study. It shows for each organizational attribute the number of studies found to be significant or in agreement with the hypothesis and the number of studies found to be insignificant or in disagreements with the hypothesis.

\begin{tabular}{lccccc}
\hline \multicolumn{1}{c}{ Organizational factors } & No. of Studies & No of Innovation & Significant & Not Significant & \% Significance \\
\hline \hline Organizational Size & 26 & 46 & 28 & 18 & 61 \\
IT Expertise & 18 & 32 & 25 & 7 & 78 \\
Top Management Support & 24 & 31 & 24 & 7 & 77 \\
Resources & 11 & 23 & 14 & 1 & 61 \\
IS Department Size & 4 & 15 & 12 & 4 & 93 \\
IS Infrastructure & 9 & 16 & 5 & 12 & 75 \\
Formalization & 9 & 17 & 8 & 29 \\
Centralization & 6 & 16 & 10 & 2 & 50 \\
Organizational Readiness & 10 & 7 & 5 & 71 \\
Product Champion & 5 & 7 & & 2 \\
\hline
\end{tabular}

Table 3: Aggregated significance test result 
In terms of the percentage, $93 \%$ of studies found IS department size significant while organizational readiness and IT expertise were found to be significant by $83 \%$ and $78 \%$ studies, respectively. Only $29 \%$ of the studies found formalization, a factor relevant to IT innovation adoption. Hedges and Olkin [33] suggests that if the majority of studies obtained statistically significant results, this could be evidence that a relationship exists between the variable and IT adoption. Thus, aggregated test of significance showed that except for formalization, all other organizational variables were found to have a relationship with IT adoption.

The aggregated test of significance does not provide the magnitude and direction of the each attribute to IT adoption. In addition, the results do not provide any mechanism for generalizing and identifying the impact of different organizational attributes for IT adoption. However, significance tests demonstrated the inconsistency of findings in the studies.

\subsection{Meta-analysis summary of findings}

The study conducted meta-analysis procedures for ten organizational characteristics that influenced the adoption of IT. We extracted studies that provided correlation values. Thirty-one studies were used to carry out the meta-analysis procedures; from these thirty-one studies, fifty-seven sets of correlation values with IT innovation adoption relationship were obtained.

\subsubsection{Overall findings}

Table 4 shows the meta-analysis results of relationship between the ten organizational factors and IT adoption. The second and the third columns show the total number of innovation relationships (INN STD) and total sample size (SAM SIZ), respectively for each individual organizational attribute. It also shows the computed mean correlation (MEN COR) for each individual variable and Fisher's ztransformation value for the mean correlation (ZTR VAL). This is followed by calculated values for observed variance (OBS VAR) and sampling error due to variance (SAM EVA). Mean correlation value depicts the overall strength of the each variable in relation to IT adoption. The EXP VAR column gives the percentage of 'explained variance' for each organizational attribute. The percentage of explained variance determines if individual organization characteristics require examination for a moderator effect. Finally, the last column (COF INT) gives the 95\% confidence interval showing the association between organizational variable and IT adoption and gives an estimated range of values representing its association.

\begin{tabular}{|c|c|c|c|c|c|c|c|c|}
\hline & INN STD & SAM SIZ & MEN COR & ZTR VAL & OBS VAR & SAM EVA & EXP VAR & COF INT \\
\hline Organizational Size & 30 & 13537 & 0.177 & 0.179 & 0.015 & 0.002 & 14 & $0.16,0.20$ \\
\hline IT Expertise & 19 & 6121 & 0.265 & 0.272 & 0.039 & 0.003 & 7 & $0.25,0.30$ \\
\hline Top Management Support & 13 & 2205 & 0.281 & 0.289 & 0.010 & 0.005 & 48 & $0.25,0.33$ \\
\hline Resources & 19 & 8311 & 0.208 & 0.211 & 0.026 & 0.002 & 8 & $0.19,0.23$ \\
\hline IS Department Size & 12 & 4922 & 0.402 & 0.426 & 0.010 & 0.002 & 16 & $0.40,0.45$ \\
\hline IS Infrastructure & 10 & 7126 & 0.283 & 0.291 & 0.015 & 0.001 & 8 & $0.27,0.31$ \\
\hline Formalization & 10 & 1545 & 0.093 & 0.093 & 0.030 & 0.006 & 21 & $0.04,0.14$ \\
\hline Centralization & 9 & 1494 & -0.029 & -0.029 & 0.050 & 0.006 & 12 & $-0.08,0.02$ \\
\hline Organizational Readiness & 2 & 193 & 0.698 & 0.863 & 0.002 & 0.002 & 100 & $0.72,1.00$ \\
\hline Product Champion & 2 & 402 & 0.019 & 0.019 & 0.003 & 0.003 & 100 & $-0.08,0.12$ \\
\hline
\end{tabular}

No. of Innovation Studied - INN STD, Sample Size - SAM SIZ, Mean Correlation - MEN COR, ZTR VAL - Z- Transformation,

Observed Variance - OBS VAR, Sampling Error Variance - SAM EVA, Explain Variance - EXP VAR, 95\% Confidence Interval - COF INT

Table 4: Meta-analysis results of organizational factors 
The meta-analysis results confirmed the relationship between organizational attributes and IT innovation adoption except for formalization, centralization and product champion. Mean correlation results showed that the strongest relationship with innovation adoption was organizational readiness (strong significance - correlation value between \pm 0.50 to \pm 0.69 ). The impact of organizational readiness on IT adoption was evident from the twelve reviewed studies on the variable, of which ten found significance [35, 52]. However, this meta-analysis result needs to be considered with caution since only two innovation adoption relationships were used. The study was not able to perform moderator effects for organizational readiness partly due to lack of innovation adoption relationships and because the sampling error variance of the variable was found to be more than $60 \%$.

The results also suggest that IS department size has a moderate significance (correlation value between \pm 0.30 to \pm 0.49 ) relationship. The results show that IS infrastructure, top management support, IT expertise, resources and organizational size had only a weak significance with IT adoption (correlation value between \pm 0.10 to \pm 0.29 ). We expected organizational resources and organizational size to be more influential in organizational IT adoption. One possible reason for this result might be the relatively low setup cost of IT in the past few years. Equally, the amount of resources that has to be committed to adopt IT has become minimal. Also, managers are aware of the benefits of IT and might be less reluctant to commit resources to IT adoption.

The mean correlation results of formalization, centralization and product champion showed insignificance (correlation value between 0 to \pm 0.09 ) for the relationship between these variables and IT adoption. The reviewed literature suggests that formalization and centralization were two variables which demonstrated the largest inconsistencies in findings. The result for formalization was consistent with the meta-analysis result of organizational attributes by Damanpour [17]. However, Damanpour [17] found centralization to have significant and negative association with IT adoption. The result for product champion needs further justification. Only two innovation adoption relationships were used to perform the meta-analysis of product champion. More than $70 \%$ of studies that investigated product champion found it to be a significant attribute in IT adoption.

The results of $95 \%$ confidence interval found an association (interval does not include zero) with IT adoption except centralization and product champion. Centralization and product champion were not found to be associated (interval includes zero) with IT adoption. For formalization, most past studies suggest a negative association [17,81]; our meta-analysis found a positive association with innovation adoption. This implies that rather than inhibiting adoption, formalization facilitates adoption by following rules and use of formal procedures. Olson and Chervany [58] state that formalization permits better decentralization of IS development and the smooth management of IS projects. Ein-Dor and Segev [24] found that formal and complete documentation allows organizations to be more successful in Management Information Systems (MIS). The study performed the moderator effect on the relationship between formalization and IT adoption, results from which are explained in Section 6.6.1. The result for explained variance (EXP VAR) showed that except for organizational readiness and product champion, all other factors have sampling error variance less than $60 \%$ of the observed variance.

\section{Discussion}

\subsection{Organizational Size}

Organizational size has been the most frequently examined factor in the study of organizational innovation adoption $[46,64,87]$. As size of an organization determines other organizational aspects, particularly slack resources, decision-making and organizational structure, organizational size is the most important factor influencing IT adoption [71]. However, the impact of organizational size on IT adoption is mixed; in some studies it is found to be an important attribute [64] while other research 
has found it to be insignificant [32]. With regard to organizational size, researchers have found that availability of slack resources in larger organizations facilitates innovation adoption [97]. Researchers have also argued that flexible organizational structure and centralized decision-making in smaller organizations assists innovation adoption [98]. As a result, effect of organization size on the initiation, adoption and implementation of IT has produced inconclusive results [67].

In the IT literature, several studies found a significant relationship between organization size and IT adoption [85, 86] while others found no significant effect [7, 32]. Nevertheless, most research has hypothesized that the larger organizations tended to adopt IT more rapidly than small organizations. Hence, we might expect a positive relationship between organizational size and IT innovation adoption.

\subsubsection{Findings of moderator effect on organizational size}

Table 5 illustrates the results of the meta-analysis of moderator effects on the relationship between organizational size and adoption of IT.

\begin{tabular}{|c|c|c|c|c|c|c|c|c|}
\hline Moderator & INN STD & SAM SIZ & MEN COR & ZTR VAL & OBS VAR & SAM EVA & EXP VAR & COF INT \\
\hline \multicolumn{9}{|l|}{ Stage of Innovation } \\
\hline Initiation & 2 & 3133 & 0.175 & 0.177 & 0.006 & 0.001 & 10 & $0.14,0.21$ \\
\hline Adoption & 18 & 6276 & 0.186 & 0.188 & 0.014 & 0.003 & 19 & $0.16,0.21$ \\
\hline Implementation & 8 & 3921 & 0.162 & 0.163 & 0.018 & 0.002 & 11 & $0.13,0.19$ \\
\hline Mixed & 2 & 207 & 0.238 & 0.243 & 0.063 & 0.009 & 14 & $0.11,0.38$ \\
\hline \multicolumn{9}{|l|}{ Type of Innovation } \\
\hline Product & 14 & 7282 & 0.110 & 0.11 & 0.010 & 0.002 & 19 & $0.09,0.13$ \\
\hline Process & 13 & 5501 & 0.238 & 0.243 & 0.006 & 0.002 & 33 & $0.22,0.27$ \\
\hline Mixed & 3 & 754 & 0.386 & 0.407 & 0.006 & 0.003 & 49 & $0.34,0.48$ \\
\hline \multicolumn{9}{|l|}{ Type of organization } \\
\hline Manufacturing & 5 & 324 & 0.272 & 0.279 & 0.015 & 0.013 & 87 & $0.17,0.39$ \\
\hline Service & 9 & 1727 & 0.191 & 0.193 & 0.024 & 0.005 & 20 & $0.15,0.24$ \\
\hline Mixed & 16 & 11486 & 0.173 & 0.175 & 0.013 & 0.001 & 10 & $0.16,0.19$ \\
\hline \multicolumn{9}{|l|}{ Size of Organization } \\
\hline Large & 11 & 1705 & 0.121 & 0.122 & 0.025 & 0.006 & 25 & $0.07,0.17$ \\
\hline SMEs & 5 & 1053 & 0.269 & 0.276 & 0.042 & 0.004 & 10 & $0.22,0.34$ \\
\hline Mixed & 14 & 10779 & 0.177 & 0.179 & 0.009 & 0.001 & 14 & $0.16,0.20$ \\
\hline
\end{tabular}

No. of Innovation Studied - INN STD, Sample Size - SAM SIZ, Mean Correlation - MEN COR, ZTR VAL - Z- Transformation,

Observed Variance - OBS VAR, Sampling Error Variance - SAM EVA, Explain Variance - EXP VAR, 95\% Confidence Interval - COF INT

Table 5: Meta-analysis result of organizational size

For all the subgroups categorized by stage of innovation (initiation, adoption, implementation and mixed), mean correlation and 95\% confidence intervals verified a significant (value $>0.10$ ) and positive association (confidence interval does not include zero) between organizational size and IT adoption. The results for mean correlation suggest that organizational size was a more significant attribute for process innovation than product innovation. These results can be explained by the fact that process innovation involves replacing the entire system or work procedure; small organizations will not therefore generally have the required resources for such a change [85]. Size of organization was a better determinant of IT adoption in manufacturing organizations than service organizations. One explanation for this result could be that manufacturing sectors are more vulnerable to social pressure and anticipation of their co-workers, compared with service organizations; hence, manufacturing organizations are more likely to adopt IT due to competitive pressure [9].

It is important to note the weak significance (correlation value between \pm 0.10 to \pm 0.29 ) of size to IT adoption in most moderating conditions. This validates the fact that organizations of all types and sizes have realised the benefit of IT and have been utilising IT in their operations. The cost of IT has reduced drastically and even small organizations can afford to utilize specialised technologies. The result of organizational size from the meta-analysis by Lee and Xia [48] were more significant than 
our results. In this study, we included more recent studies and hence this might have influenced our overall result in this case. It would be worthwhile to investigate this variable under a new moderator condition 'year of study', to find the effect of organizational size factor.

We expected organizational size to have a stronger significance than the study suggested, as size determines other organizational factors such as slack resources and decision-making which in particular impacts small organizations. One reason for this weak significance might be that the metaanalysis was performed using more studies for large organizations. Larger organizations are able to allocate resources more easily and can invest on new technologies more rapidly.

\subsection{IT expertise}

In an organization, knowledge of IT is a major factor in the adoption of new technologies [27]. Organizations which possess the awareness of IT may have a better idea of new technology and the benefits they may bring to achieve organizational objectives. An organization with existing knowledge of new innovation makes adoption effortless and retains knowledge for innovation adoption [49].

The IT literature shows that IT expertise is a key determinant of organizational innovation adoption $[44,86]$. In this review study, IT expertise was examined by eighteen researchers. The number of relationships between IT expertise and IT adoption found were thirty-two. As can be seen from Table 3 , twenty-five studies concluded that IT expertise possessed a significant relationship with IT adoption while seven studies revealed otherwise. As the majority of studies showed a significant relationship, applying the suggestion by Hedges and Olkin [33] we conclude that IT expertise is one of the major factors facilitating innovation adoption in an organization. The result of $95 \%$ confidence interval confirmed the association between IT expertise and IT adoption (Table 4). Mean correlation of the meta-analysis confirmed a weakly significant relationship (correlation value between \pm 0.10 to \pm 0.29 ) between IT expertise and IT innovation adoption.

\subsubsection{Findings of moderator effect on IT expertise}

\begin{tabular}{|c|c|c|c|c|c|c|c|c|}
\hline Moderator & INN STD & SAM SIZ & MEN COR & ZTR VAL & OBS VAR & SAM EVA & EXP VAR & COF INT \\
\hline \multicolumn{9}{|l|}{ Stage of Innovation } \\
\hline Initiation & 0 & & & & & & & \\
\hline Adoption & 9 & 2574 & 0.360 & 0.377 & 0.044 & 0.003 & 6 & $0.34,0.42$ \\
\hline Implementation & 6 & 1115 & 0.341 & 0.355 & 0.005 & 0.004 & 91 & $0.30,0.41$ \\
\hline Mixed & 4 & 2432 & 0.130 & 0.131 & 0.018 & 0.002 & 9 & $0.09,0.17$ \\
\hline \multicolumn{9}{|l|}{ Type of Innovation } \\
\hline Product & 14 & 5431 & 0.255 & 0.261 & 0.042 & 0.002 & 5 & $0.23,0.29$ \\
\hline Process & 3 & 102 & 0.353 & 0.369 & 0.016 & 0.016 & 100 & $0.17,0.57$ \\
\hline Mixed & 2 & 588 & 0.342 & 0.356 & 0.003 & 0.003 & 85 & $0.27,0.44$ \\
\hline \multicolumn{9}{|l|}{ Type of organization } \\
\hline Manufacturing & 5 & 324 & 0.229 & 0.233 & 0.012 & 0.012 & 100 & $0.12,0.34$ \\
\hline Service & 1 & 135 & 0.530 & 0.590 & 0.000 & 0.000 & 0 & $0.40,0.76$ \\
\hline Mixed & 13 & 5662 & 0.261 & 0.267 & 0.039 & 0.002 & 5 & $0.24,0.29$ \\
\hline \multicolumn{9}{|l|}{ Size of Organization } \\
\hline Large & 0 & & & & & & & \\
\hline SMEs & 6 & 1406 & 0.502 & 0.552 & 0.030 & 0.002 & 8 & $0.50,0.60$ \\
\hline Mixed & 13 & 4715 & 0.195 & 0.198 & 0.019 & 0.003 & 13 & $0.17,0.23$ \\
\hline
\end{tabular}

No. of Innovation Studied - INN STD, Sample Size - SAM SIZ, Mean Correlation - MEN COR, ZTR VAL - Z- Transformation,

Observed Variance - OBS VAR, Sampling Error Variance - SAM EVA, Explain Variance - EXP VAR, 95\% Confidence Interval - COF INT

Table 6: Meta-analysis result of IT expertise

The meta-analysis results of the moderator effect on the relationship between IT expertise and adoption of IT are shown in Table 6 . The mean correlation and 95\% confidence interval verified that 
all four moderators examined influenced the relationship between IT expertise and IT adoption. This result is consistent with past literature $[25,74,86]$. IT expertise was a better determinant for process innovation compared with product innovation. One explanation for this might be that the extent of IT expertise required for an organization is greater for process innovation, since it involves changing the entire system or work procedure.

One of the important findings of the moderator effect on the relationship between IT expertise and IT adoption was its significance (strong significance - correlation value between \pm 0.5 to \pm 0.69 ) for small organizations. Lack of IT expertise and the insufficient knowledge of the benefits of innovation inhibit small businesses from adopting IT. Small organizations usually seek assistance from IT consulting firms or IT vendors for IT adoption. Using an external source, IT can be adopted with ease; however, without in-house IT expertise, small organizations might struggle to sustain its continuous use.

\subsection{Top Management Support}

A recurring, organizational factor studied by IS researchers is top management support. Top management support is one of the consistently found and highly critical factors influencing IT implementations [88]. It is commonly believed that top management support plays a vital role in all stages of IT adoption [67]. Top management's role in allocating required resources and providing a supportive climate in user acceptance of innovation is important [32]. There is also evidence in the innovation literature which suggests that top management support is positively related to the adoption of new technologies in organizations [90].

In the process of reviewing studies of IT adoption, we gathered twenty-four studies which examined top management support with thirty-one sets of IT innovation relationships; twenty-four of these showed a positive relationship, while seven showed an insignificant association with IT innovation adoption. Significance tests revealed the importance of top management support in the innovation adoption in organization. To verify the effect of top management support on IT adoption using metaanalysis, we considered ten studies with thirteen relationships. As shown in Table 4, a 95\% confidence interval verified the association between top management support and IT adoption. Mean correlation results of the meta-analysis showed that top management support had only a weak significance (correlation value between \pm 0.10 to \pm 0.29 ) on adoption of IT.

\subsubsection{Findings of moderator effect on top management support}

Table 7 illustrates the results of the moderator effects on the relationship between top management support and IT adoption. The mean correlation and 95\% confidence interval of all four moderators showed significant (values $>0.10$ ) and positive association (confidence interval does not include zero) between top management support and IT adoption. This result supports past findings of top management support $[5,23,40]$.

One notable result of moderator effect showed that top management support was more significant for larger organizations (moderate significance - correlation value between \pm 0.30 to \pm 0.49 ) than small organizations (weak significance - correlation value between \pm 0.10 to \pm 0.29 ). However, the literature suggests that management support may be much more important in small organizations compared to larger ones [36]. One possible explanation might be that the top management support in allocating sufficient resources for adoption is overshadowed by lack of resources in small organizations that contributed more to the adoption of IT. Another explanation could be that in small organizations, the top manager is usually the owner and makes all key organizational decisions including adoption of new IT. Instead, in large organizations, middle management is usually involved in the adoption process and they require full support from top management to commit necessary resources for IT adoption and implementation. 


\begin{tabular}{|c|c|c|c|c|c|c|c|c|}
\hline Moderator & INN STD & SAM SIZ & MEN COR & ZTR VAL & OBS VAR & SAM EVA & EXP VAR & COF INT \\
\hline \multicolumn{9}{|l|}{ Stage of Innovation } \\
\hline Initiation & 0 & & & & & & & \\
\hline Adoption & 7 & 894 & 0.309 & 0.319 & 0.014 & 0.006 & 45 & $0.25,0.38$ \\
\hline Implementation & 6 & 1311 & 0.261 & 0.267 & 0.007 & 0.004 & 59 & $0.21,0.32$ \\
\hline Mixed & 0 & & & & & & & \\
\hline \multicolumn{9}{|l|}{ Type of Innovation } \\
\hline Product & 10 & 1445 & 0.316 & 0.327 & 0.012 & 0.006 & 49 & $0.28,0.38$ \\
\hline Process & 1 & 358 & 0.200 & 0.203 & 0.000 & 0.000 & 0 & $0.10,0.31$ \\
\hline Mixed & 2 & 402 & 0.227 & 0.231 & 0.002 & 0.002 & 100 & $0.13,0.33$ \\
\hline \multicolumn{9}{|l|}{ Type of organization } \\
\hline Manufacturing & 2 & 409 & 0.234 & 0.238 & 0.008 & 0.004 & 55 & $0.14,0.34$ \\
\hline Service & 0 & & & & & & & \\
\hline Mixed & 11 & 1796 & 0.291 & 0.300 & 0.010 & 0.005 & 50 & $0.25,0.35$ \\
\hline \multicolumn{9}{|l|}{ Size of Organization } \\
\hline Large & 4 & 754 & 0.330 & 0.343 & 0.004 & 0.004 & 100 & $0.27,0.41$ \\
\hline SMEs & 5 & 629 & 0.273 & 0.280 & 0.024 & 0.007 & 28 & $0.20,0.36$ \\
\hline Mixed & 4 & 822 & 0.241 & 0.246 & 0.002 & 0.002 & 100 & $0.18,0.31$ \\
\hline
\end{tabular}

No. of Innovation Studied - INN STD, Sample Size - SAM SIZ, Mean Correlation - MEN COR, ZTR VAL - Z- Transformation,

Observed Variance - OBS VAR, Sampling Error Variance - SAM EVA, Explain Variance - EXP VAR, 95\% Confidence Interval - COF INT

Table 7: Meta-analysis result of top management support

\subsection{Resources}

In theory, availability of resources has a strong impact on IT adoption. Organizational slack resources may be a fundamental ingredient for innovation adoption [46]. Resources include financial, technological and human resources. Financial resources refers to the availability of funding for IS investment. IS literature has suggested that financial resources have a significant impact on all stages of innovation adoption of IT. Technological resources are the IT infrastructure installed in the organization, while human resources are the existing IT knowledge within that organization. Lack of technological infrastructure and IT knowledge can be a major barrier for IT adoption [94]. The majority of IT literature found resources to have a positive association with IT innovation adoption and use $[28,57,81]$.

In this study, we drew together eleven studies that considered resources and the influence it had on innovation adoption. Twenty-three sets of IT innovation relationships with resources were explored, out of which fourteen were found to be significant and nine insignificant. Despite the importance of organizational resources to IT adoption, the significance test results were inconclusive. A total of nineteen sets of correlation relationships were used to perform meta-analysis on resources with IT adoption. These nineteen relationships were drawn from eight studies. The 95\% confidence interval confirmed the association between resources and IT adoption. However, results of mean correlation of the meta-analysis showed that resources available in an organization had a weak significance (correlation value between \pm 0.10 to \pm 0.29 ) in IT adoption.

\subsubsection{Findings of moderator effect on resources}

Table 8 illustrates the results of the meta-analysis of the moderator effect on the relationship between resources and adoption of IT. The result indicates that the stage of innovation was a significant moderator for the relationship between resources and IT adoption. The mean correlation result suggests that resources were a better determinant of the implementation stage of adoption (weak significance - correlation value between \pm 0.10 to \pm 0.29 ) compared to other two stages. This result validates the past literature which showed that more resources are required in the implementation stage of innovation adoption $[68,94]$. Results found weak significance (correlation value between \pm 0.10 to \pm 0.29 ) between resources and IT adoption for both product and process innovation. 


\begin{tabular}{|c|c|c|c|c|c|c|c|c|}
\hline Moderator & INN STD & SAM SIZ & MEN COR & ZTR VAL & OBS VAR & SAM EVA & EXP VAR & COF INT \\
\hline \multicolumn{9}{|l|}{ Stage of Innovation } \\
\hline Initiation & 1 & 1276 & 0.11 & 0.110 & 0.000 & 0.000 & 0 & $0.06,0.16$ \\
\hline Adoption & 11 & 4244 & 0.180 & 0.182 & 0.023 & 0.002 & 11 & $0.15,0.21$ \\
\hline Implementation & 6 & 2705 & 0.297 & 0.306 & 0.030 & 0.002 & 6 & $0.27,0.34$ \\
\hline Mixed & 1 & 86 & 0.209 & 0.212 & 0.000 & 0.000 & 0 & $0.00,0.43$ \\
\hline \multicolumn{9}{|l|}{ Type of Innovation } \\
\hline Product & 4 & 430 & 0.236 & 0.241 & 0.008 & 0.008 & 100 & $0.15,0.34$ \\
\hline Process & 15 & 7881 & 0.206 & 0.209 & 0.027 & 0.002 & 6 & $0.19,0.23$ \\
\hline Mixed & 0 & & & & & & & \\
\hline \multicolumn{9}{|l|}{ Type of organization } \\
\hline Manufacturing & 3 & 102 & 0.023 & 0.023 & 0.014 & 0.014 & 100 & $-0.17,0.22$ \\
\hline Service & 11 & 2001 & 0.112 & 0.112 & 0.033 & 0.005 & 16 & $0.07,0.16$ \\
\hline Mixed & 5 & 6208 & 0.242 & 0.247 & 0.019 & 0.001 & 4 & $0.22,0.27$ \\
\hline \multicolumn{9}{|l|}{ Size of Organization } \\
\hline Large & 8 & 1002 & 0.068 & 0.068 & 0.057 & 0.008 & 14 & $0.01,0.13$ \\
\hline SMEs & 2 & 274 & 0.225 & 0.229 & 0.011 & 0.007 & 60 & $0.11,0.35$ \\
\hline Mixed & 9 & 7035 & 0.227 & 0.231 & 0.019 & 0.001 & 6 & $0.21,0.25$ \\
\hline
\end{tabular}

No. of Innovation Studied - INN STD, Sample Size - SAM SIZ, Mean Correlation - MEN COR, ZTR VAL - Z- Transformation,

Observed Variance - OBS VAR, Sampling Error Variance - SAM EVA, Explain Variance - EXP VAR, 95\% Confidence Interval - COF INT

\section{Table 8: Meta-analysis result of resources}

There are two critical findings from the results of moderator effects on the relationship between resources and IT adoption. First, the significance of resources for the implementation stage of adoption compared to initiation and adoption stages. The literature also suggests that a successful implementation requires a substantial financial investment and competent human resources $[57,68]$. In the initiation and adoption decision stages, the organization is involved only in evaluating and promoting the new innovation among its members. However, it is the implementation stage of IT where the organization seeks the availability of necessary funds and experts.

Second, the meta-analysis results verified a weakly significant relationship (correlation value between \pm 0.10 to \pm 0.29 ) between resources and IT adoption for small organizations compared to an insignificant relationship (correlation value between \pm 0 to \pm 0.09 ) with large organizations in IT adoption. Large organizations possess more financial, technical and human resources and can take risks by committing these resources. In the event of implementation failure, small organizations suffer more, since the initial investment of IT would likely to be a relatively larger part of the organization's budget.

\subsection{IS Department Size}

The relationship between IS department size is likely to have a significant impact in the adoption of IT innovation. Empirical evidence suggests that IS department size has a positive influence on all stages of IT adoption [32]. A larger IS department size means that the organization possesses more IT resources and technical skills which, in turn, facilitates innovation adoption.

Among the studies reviewed, four studies empirically examined the relationship between IS department size and IT adoption. In these four studies, fifteen innovation adoption relationships with IS department size were observed. Results revealed that fourteen relationships found significant associations and only one was found to have no significance. To perform a meta-analysis on IS department size, a set of twelve IT adoption relationships from three studies were considered. The meta-analysis results of mean correlation and 95\% confidence interval showed IS department size to be a significant predictor of innovation adoption of IT. 


\subsubsection{Findings of moderator effect on IS department size}

Table 9 illustrates the meta-analysis results of the moderator effects on the relationship between IS department size and adoption of IT.

\begin{tabular}{|c|c|c|c|c|c|c|c|c|}
\hline Moderator & INN STD & SAM SIZ & MEN COR & ZTR VAL & OBS VAR & SAM EVA & EXP VAR & COF INT \\
\hline \multicolumn{9}{|l|}{ Stage of Innovation } \\
\hline Initiation & 1 & 82 & 0.000 & 0.000 & 0.090 & 0.090 & 100 & $-0.22,0.22$ \\
\hline Adoption & 4 & 1508 & 0.171 & 0.173 & 0.066 & 0.003 & 4 & $0.12,0.22$ \\
\hline Implementation & 3 & 900 & 0.322 & 0.334 & 0.001 & 0.001 & 100 & $0.27,0.40$ \\
\hline Mixed & 4 & 2432 & 0.000 & 0.000 & 0.200 & 0.002 & 1 & $-0.04,0.04$ \\
\hline \multicolumn{9}{|l|}{ Type of Innovation } \\
\hline Product & 12 & 4922 & 0.209 & 0.212 & 0.048 & 0.002 & 5 & $0.18,0.24$ \\
\hline Process & 0 & & & & & & & \\
\hline Mixed & 0 & & & & & & & \\
\hline \multicolumn{9}{|l|}{ Type of organization } \\
\hline Manufacturing & 0 & & & & & & & \\
\hline Service & 0 & & & & & & & \\
\hline Mixed & 12 & 4922 & 0.209 & 0.212 & 0.048 & 0.002 & 5 & $0.18,0.24$ \\
\hline \multicolumn{9}{|l|}{ Size of Organization } \\
\hline Large & 3 & 246 & 0.253 & 0.259 & 0.001 & 0.001 & 100 & $0.13,0.38$ \\
\hline SMEs & 0 & & & & & & & \\
\hline Mixed & 9 & 4676 & 0.000 & 0.000 & 0.178 & 0.002 & 1 & $-0.03,0.03$ \\
\hline
\end{tabular}

No. of Innovation Studied - INN STD, Sample Size - SAM SIZ, Mean Correlation - MEN COR, ZTR VAL - Z- Transformation,

Observed Variance - OBS VAR, Sampling Error Variance - SAM EVA, Explain Variance - EXP VAR, 95\% Confidence Interval - COF INT

Table 9: Meta-analysis result of IS department size

The result of the meta-analysis indicates that stage of innovation was a significant moderator of the relationship between IS department size and IT adoption. The mean correlation suggests that IS department size was most significant for the implementation stage of IT adoption (moderate significance - correlation value between \pm 0.30 to \pm 0.49 ). This supports past literature which suggests the importance of IS department size in the propagation of IT [66]. The size of IT department usually depicts the amount of technical competency within the organization. The larger the size of the IT department, the more the technical and human resources exist within the organization. For a successful implementation of IT, organizations require a large amount of IT expertise. Hence, the size of IS department influences a successful implementation of new innovation. Implementation of complex innovation requires more IT functions within the organization.

\subsection{Formalization}

Formalization is the degree to which an organization follows the rules and procedures on the role of performance of its members [70]. In an IT context, formalization can also be considered as an IS structure or technology strategy within an organization. In the IS literature, formalization has been hypothesized to have a negative association with initiation and adoption stages and a positive association with the implementation stage [32]. The literature has found conflicting empirical evidence for the relationship between formalization and IT innovation adoption.

Out of fifty-nine studies, nine studies assessed formalization. Seventeen relationships with formalization and IT adoption were studied and five studies found formalization significant while twelve studies were found to have no relevance. From the significance test results, no real judgement can be made on formalization with regard to its influence on IT adoption. The meta-analysis procedure for formalization considered ten sets of formalization IT adoption relationships from four different studies. 
The mean correlation result of the meta-analysis revealed that formalization in an organization was found to have no significance with the adoption of IT (correlation value between \pm 0 to \pm 0.09 ). The 95\% confidence interval results of the meta-analysis showed a positive association but theory suggests a negative association. As described previously, we found significant divergence from previous studies on formalization; some researchers advocate that adherence to rules and procedure facilitates IT adoption $[24,46]$.

\subsubsection{Findings of moderator effect on formalization}

Table 10 illustrates the results of the meta-analysis of the moderator effects on the relationship between formalization and adoption of IT.

\begin{tabular}{|c|c|c|c|c|c|c|c|c|}
\hline Moderator & INN STD & SAM SIZ & MEN COR & ZTR VAL & OBS VAR & SAM EVA & EXP VAR & COF INT \\
\hline \multicolumn{9}{|l|}{ Stage of Innovation } \\
\hline Initiation & 0 & & & & & & & \\
\hline Adoption & 7 & 1127 & 0.057 & 0.057 & 0.032 & 0.006 & 19 & 0.00 .0 .12 \\
\hline Implementation & 2 & 332 & 0.200 & 0.203 & 0.014 & 0.006 & 40 & $0.09,0.31$ \\
\hline Mixed & 1 & 86 & 0.147 & 0.148 & 0.000 & 0.000 & 0 & $-0.07,0.36$ \\
\hline \multicolumn{9}{|l|}{ Type of Innovation } \\
\hline Product & 4 & 699 & 0.153 & 0.154 & 0.009 & 0.005 & 62 & $0.08,0.23$ \\
\hline Process & 6 & 846 & 0.043 & 0.043 & 0.042 & 0.007 & 17 & $-0.02,0.11$ \\
\hline Mixed & 0 & & & & & & & \\
\hline \multicolumn{9}{|l|}{ Type of organization } \\
\hline Manufacturing & 1 & 51 & 0.477 & 0.519 & 0.000 & 0.000 & 0 & $0.24,0.80$ \\
\hline Service & 7 & 932 & 0.053 & 0.053 & 0.219 & 0.008 & 3 & $-0.01,0.12$ \\
\hline Mixed & 2 & 562 & 0.125 & 0.126 & 0.006 & 0.003 & 59 & $0.04,0.21$ \\
\hline \multicolumn{9}{|l|}{ Size of Organization } \\
\hline Large & 10 & 1545 & 0.093 & 0.093 & 0.039 & 0.006 & 17 & $0.04,0.14$ \\
\hline SMEs & 0 & & & & & & & \\
\hline Mixed & 0 & & & & & & & \\
\hline
\end{tabular}

No. of Innovation Studied - INN STD, Sample Size - SAM SIZ, Mean Correlation - MEN COR, ZTR VAL - Z- Transformation,

Observed Variance - OBS VAR, Sampling Error Variance - SAM EVA, Explain Variance - EXP VAR, 95\% Confidence Interval - COF INT

Table 10: Meta-analysis result of formalization

The meta-analysis results of moderator effect of stage of innovation on the relationship between formalization and IT adoption revealed an interesting result. The $95 \%$ confidence interval verified a positive association (interval does not include zero) between adoption and implementation stages of IT adoption. Although the meta-analysis results for formalization and IT innovation adoption were found to be insignificant, the meta-analysis moderator of the stage of innovation confirmed a weak significance relationship (correlation value between \pm 0.10 to \pm 0.29 ) with the implementation stage and insignificance (correlation value between 0 to \pm 0.09 ) with the adoption stage. Grover and Goslar [32] found no relationship between formalization and IT adoption for the initiation, adoption and implementation of IT. However, the meta-analysis moderator effect results we obtained corroborate the findings of Moch and Morse [55].

The mean correlation and $95 \%$ confidence interval results of meta-analysis found that formalization was positively associated (interval does not include zero) with weak significance (correlation value between \pm 0.10 to \pm 0.29 ) with the adoption of product innovation while no significance (correlation value between 0 to \pm 0.09 ) was found with process innovation.

\subsection{Centralization}

Centralization is the degree to which power and control are concentrated in the hands of relatively few individuals in an organization [70]. Centralization of an organization has a negative relationship with initiation and adoption, but has a positive relationship with implementation [32]. Rogers [70] found 
that centralization initially inhibited innovation, but is facilitated once innovation is in place. IS literature shows a positive association between centralization and adoption of innovation for some studies but in others shows a negative relationship.

Centralization was considered in six of our reviewed literature studies with sixteen IT adoption relationships. The aggregated significant test results of centralization showed eight significant and eight insignificant relationships. For the meta-analysis, nine centralization-IT adoption relationships were gathered from three studies which performed correlation analysis. The $95 \%$ confidence interval of meta-analysis showed that centralization had no significance in the adoption of IT.

\subsubsection{Findings of moderator effect on centralization}

\begin{tabular}{|c|c|c|c|c|c|c|c|c|}
\hline Moderator & INN STD & SAM SIZ & MEN COR & ZTR VAL & OBS VAR & SAM EVA & EXP VAR & COF INT \\
\hline \multicolumn{9}{|l|}{ Stage of Innovation } \\
\hline \multicolumn{9}{|l|}{ Initiation } \\
\hline Adoption & 7 & 1127 & -0.001 & -0.001 & 0.065 & 0.006 & 10 & $-0.06,0.06$ \\
\hline Implementation & 1 & 281 & 0.080 & 0.08 & 0.000 & 0.000 & 0 & $-0.04,0.20$ \\
\hline Mixed & 1 & 86 & -0.142 & -0.143 & 0.000 & 0.000 & 0 & $-0.36,0.07$ \\
\hline \multicolumn{9}{|l|}{ Type of Innovation } \\
\hline Product & 3 & 648 & 0.055 & 0.055 & 0.006 & 0.005 & 78 & $-0.02,0.13$ \\
\hline Process & 6 & 846 & -0.032 & -0.032 & 0.079 & 0.007 & 9 & $-0.10,0.04$ \\
\hline \multicolumn{9}{|l|}{ Mixed } \\
\hline \multicolumn{9}{|l|}{ Type of organization } \\
\hline \multicolumn{9}{|l|}{ Manufacturing } \\
\hline Service & 7 & 932 & -0.042 & -0.042 & 0.071 & 0.008 & 11 & $-0.11,0.02$ \\
\hline Mixed & 2 & 562 & 0.085 & 0.085 & 0.000 & 0.000 & 0 & $0.00,0.17$ \\
\hline \multicolumn{9}{|l|}{ Size of Organization } \\
\hline Large & 9 & 1494 & 0.006 & 0.006 & 0.052 & 0.006 & 12 & $-0.04,0.060$ \\
\hline \multicolumn{9}{|l|}{ SMEs } \\
\hline Mixed & & & & & & & & \\
\hline
\end{tabular}

No. of Innovation Studied - INN STD, Sample Size - SAM SIZ, Mean Correlation - MEN COR, ZTR VAL - Z- Transformation,

Observed Variance - OBS VAR, Sampling Error Variance - SAM EVA, Explain Variance - EXP VAR, 95\% Confidence Interval - COF INT

Table 11: Meta-analysis result of centralization

Table 11 illustrates the meta-analysis results of the moderator effects on the relationship between centralization and adoption of IT. The results of mean correlation and $95 \%$ confidence interval of all categories of four moderator found no association (confidence interval includes zero) with the relationship between centralization and IT adoption. The important message from this result was that centralized structure neither inhibits nor facilitates IT adoption.

It is important to note that all studies considered in this meta-analysis of the relationship between centralization and IT adoption were performed for large organizations. Normally, small organizations have a more centralized form of organization structure [62]. The study by Grover and Goslar [32] conducted for mixed-size organizations found centralized decision making to be a significant factor in the adoption and implementation of IT. Hence, performing a meta-analysis with more studies including that considered for small organizations or SMEs would be insightful.

\subsection{Organizational Readiness}

Organizational readiness is defined as the degree to which an organization has the awareness, resources, commitment and governance to adopt IT [39]. Many research studies address organizational readiness in terms of availability of financial and technological resources in organizations [30,35]. Adoption of IT has often been positively associated with organizational readiness. Twelve sets of organizational readiness and IT innovation adoption relationships were 
reviewed in this study. Combined results from significance tests found a positive association with ten relationships of organizational readiness and IT adoption while two relationships found otherwise. Significance test results confirmed organizational readiness to be a major factor determining the adoption of IT.

The mean correlation results of meta-analysis showed that organizational readiness had a strong significance for adoption of IT (correlation value between \pm 0.50 to \pm 0.69 ). This result supports earlier studies by Iacovou et al. [35] and Kuan \& Chau [44]. However, the readers must view this result with care. The meta-analysis sample size that examined organizational readiness was very small and considered only two studies. We did not perform moderator effects for organizational readiness as the evaluation showed that sampling error for the variable was not less than $60 \%$ of observed variance.

\subsection{IS Infrastructure}

IS Infrastructure is essential to successfully implement and gain advantages from IT adoption [63]. Existence of IS infrastructure makes it easier for an organization to adopt innovation. Prior studies revealed a positive association between the existence of IS infrastructure and adoption of IT [94]. Organizations with well established IS infrastructure were more likely to adopt IT innovation.

The number of studies that considered IS infrastructure in our review study was nine. Sixteen innovation adoption and IS infrastructure relationships were considered in these nine studies, with twelve studies showing IS infrastructure to have significant effect on IT adoption while four studies did not find any association. These results confirmed that IS infrastructure had a firm relationship with IT adoption. For the meta-analysis, we gathered ten relationships from five studies that related IS infrastructure with innovation adoption of IT. The mean correlation results of the meta-analysis showed IS infrastructure to have a weak significance for IT adoption (correlation value between \pm 0.10 to \pm 0.29 ).

\subsubsection{Findings of moderator effect on IS infrastructure}

Table 12 illustrates the meta-analysis results of the moderator effects on the relationship between IS infrastructure and adoption of IT.

\begin{tabular}{|c|c|c|c|c|c|c|c|c|}
\hline Moderator & INN STD & SAM SIZ & MEN COR & ZTR VAL & OBS VAR & SAM EVA & EXP VAR & COF INT \\
\hline \multicolumn{9}{|l|}{ Stage of Innovation } \\
\hline Initiation & 1 & 1857 & 0.000 & 0.000 & 0.048 & 0.001 & 1 & $-0.05,0.05$ \\
\hline Adoption & 5 & 2793 & 0.274 & 0.281 & 0.015 & 0.002 & 10 & $0.24,0.32$ \\
\hline Implementation & 4 & 2476 & 0.341 & 0.355 & 0.019 & 0.001 & 7 & $0.32,0.39$ \\
\hline Mixed & 0 & & & & & & & \\
\hline \multicolumn{9}{|l|}{ Type of Innovation } \\
\hline Product & 8 & 6724 & 0.290 & 0.299 & 0.015 & 0.001 & 7 & $0.28,0.32$ \\
\hline Process & 0 & & & & & & & \\
\hline Mixed & 2 & 402 & 0.000 & 0.000 & 0.030 & 0.005 & 17 & $-0.10,0.10$ \\
\hline \multicolumn{9}{|l|}{ Type of organization } \\
\hline Manufacturing & 0 & & & & & & & \\
\hline Service & 2 & 274 & 0.455 & 0.491 & 0.207 & 0.005 & 2 & $0.37,0.61$ \\
\hline Mixed & 8 & 6852 & 0.276 & 0.283 & 0.046 & 0.001 & 2 & $0.26,0.31$ \\
\hline \multicolumn{9}{|l|}{ Size of Organization } \\
\hline Large & 2 & 562 & -0.030 & -0.030 & 0.001 & 0.001 & 100 & $-0.11,0.05$ \\
\hline SMEs & 2 & 274 & 0.000 & 0.000 & 0.235 & 0.007 & 3 & $-0.12,0.12$ \\
\hline Mixed & 6 & 6290 & 0.000 & 0.000 & 0.098 & 0.001 & 1 & $-0.02,0.02$ \\
\hline
\end{tabular}

No. of Innovation Studied - INN STD, Sample Size - SAM SIZ, Mean Correlation - MEN COR, ZTR VAL - Z- Transformation,

Observed Variance - OBS VAR, Sampling Error Variance - SAM EVA, Explain Variance - EXP VAR, 95\% Confidence Interval - COF INT

Table 12: Meta-analysis result of IS infrastructure 
The results of mean correlation and $95 \%$ confidence interval of implementation sub-category of stages of innovation showed moderate significance (correlation value between \pm 0.30 to \pm 0.49 ) and positive association (confidence interval does not include zero) between IS infrastructure and IT adoption. This result was consistent with most of the past literature on IS infrastructure [94, 98]. One important aspect of this result was the significance of IS infrastructure for implementation stage compared to the adoption stage. Adoption stage of innovation showed a weak significance (correlation value between \pm 0.10 to \pm 0.29 ) between IS infrastructure and IT adoption. One plausible explanation would be that better IS infrastructure may be important for application integration which occurs at the IT implementation stage.

\subsection{Product Champion}

Product champion can be loosely defined as an individual who performs the task of spreading knowledge of new technology within the organization. The presence of a product champion is critical to the introduction of new technologies in organizations [63]. The existence of a product champion influences all stages of innovation adoption. In the initiation stage, the product champion will persuade management to acquire technology and creates awareness of the innovation within the organization. In the adoption stage and in the implementation stage, the product champion facilitates user acceptance by providing various types of training [63].

The existence of a product champion has been found to be an important factor in IT adoption [5, 7]. In this study, we accumulated five studies that determined the influence of product champion on innovation adoption. From the five studies, a set of seven product champion and IT adoption relationships were obtained. Aggregated test of significance results showed five significant and two insignificant relationships with product champion and IT adoption. From the results of the significance test and following Hedges and Olkin [33] suggestion, product champion might be viewed as a critical factor in the decision to adopt IT. From the five studies examined on product champion, only two studies performed correlation analysis.

The $95 \%$ confidence interval results showed that product champion had no association (interval includes a zero) in the adoption of IT. Also, the mean correlation was found to be insignificant (correlation value between 0 to \pm 0.09 ) for the relationship between product champion and IT adoption. We did not perform moderator effects for product champion since the evaluation showed that sampling error was not less than $60 \%$ of observed variance.

\section{Implications of the Research}

The results of the meta-analysis showed that the most significant organizational factor for adoption of IT was organizational readiness. This was followed by IS department size, IS infrastructure, top management support, IT expertise, resource and organizational size. The study did not establish formalization, centralization or product champion as determinant factors for IT adoption. Most past studies suggest that formalization has a negative association with IT adoption; however, the study found that it facilitated IT adoption.

The study conducted tests for moderator effects for individual organizational factors except organizational readiness and product champion. Sampling error variance of organizational readiness and product champion were found to be more than $60 \%$ of observed variance and hence moderator effects could not be performed for these two variables.

The study learnt that primary studies rarely examine the initiation stages of innovation adoption of IT. More IT adoption relationships between organizational attributes and the initiation stage of IT adoption are required to perform meta-analysis moderator effect. The initiation stage was tested for 
only organizational size factor with a small sample size and was found to be weakly significant. All organizational factors were significant for the adoption decision and implementation stages. Organizational size, IT expertise, top management support, IS infrastructure, resources and formalization were more significant for the implementation stage than the adoption decision stages.

The study also found that IT expertise, top management support and resources were significant in the adoption of both product innovation and process innovation of IT adoption. Additionally, organization size was significant for process innovation while IS infrastructure were significant for product innovation of IT adoption. IT expertise, top management support and resources were key determinants for small organizations; top management support and resources were deciding factors for large organizations.

The research allowed assessment of the current state of understanding in IT adoption in organizations and, in particular, organizational attributes influencing the adoption process. The study identified the key organizational attributes influencing the adoption of IT in organizations. In addition, it categorized different factors significantly influencing the adoption of IT in organizations under different conditions and situations. Managers involved in IT adoption need to take account of these key determinants during the innovation process. In addition, organizations should focus on relevant attributes based on the conditions on which innovation adoption becomes effective.

Compared to an individual study, the results of the meta-analysis represent a larger sample size with studies conducted in varying research settings. Aggregating information in a meta-analysis procedure enables assessment of similarities and differences amongst other study findings and relationships therein to be uncovered. The use of effect size (i.e., correlation coefficients) allowed the combination of small and non-significant effects to depict an overall view of the relationship between organizational attributes and IT innovation adoption. The literature shows that the findings of individual studies on IT innovation adoption produce contradictory outcomes. Inconsistency in the findings of individual studies is largely due to statistical error and measurement variations. In addition, difference in the interpretation of test of significance also contributes to this inconsistency. By aggregating observed correlation coefficient and examining for moderator effects, the metaanalysis presented overcame these drawbacks and explained past inconsistencies. Researchers examining the adoption of IT need to consider these drawbacks in future endeavours.

The findings of the meta-analysis moderator effect allowed the study to draw more definitive conclusions on the relationship between organizational factors and IT innovation adoption. Furthermore, they allowed identification of relationships that would not necessarily be apparent from individual studies. Research examining IT adoption needs to consider these moderating effects when generalising research findings. In addition, findings of studies in a single organization, sector or country as a unit of analysis potentially misrepresents the overall aspects of IT innovation adoption.

A number of limitations of the study presented needs to be considered. We included only studies that performed correlation analysis. Of the fifty-nine studies that examined the influence of organizational variables, only thirty-one performed correlation analysis. For some variables, the number of data sets available was inadequate to perform the meta-analysis. Meta-analysis with a large sample size could have performed differently. Similarly, the study could not evaluate the moderator factor effect for some variables due to lack of data. For the meta-analysis, we used studies that provided correlation values for the relationship between organizational attributes and IT adoption. One more limitation is that the majority of these studies were intended for large organizations and only a few studies examined small organizations. Another short-coming is that most meta-analyses experience publication bias. However, a comprehensive search was carried out to obtain all literature that examined factors influencing the adoption of IT. 


\section{Conclusions}

The findings have considerable significance in understanding the determinant of IT adoption in terms of organizational context. The study provides researchers and practitioners with a set of factors that affect the adoption of IT in organizations. Results serve as a guideline for practitioners to identify and address the facilitating and inhibiting issues in the organizational context in the process of IT adoption. Managers need to consider these important issues when embarking on IT adoption.

In the review study and meta-analysis we identified gaps in our understanding of the attributes of IT adoption due to the lack of past empirical studies. Future studies could concentrate on addressing these gaps to enhance understanding of those areas that have not been covered in past studies. In this regard, more empirical research is needed to explore the influence of organizational attributes to the initiation stage of innovation adoption. The study presented could only verify organizational size factors with two data sets for the initiation stage of innovation adoption; due to lack of past studies, we could not verify other organizational factors. Future studies should concentrate on small organizations as our meta-analysis could not verify the effect of most organizational attributes in this category. In addition, the study could not verify some moderating conditions for organizational factors considered in the meta-analysis. We encourage replication of studies in this area and, to that end; all data used in this study can be made available upon request of the lead author.

\section{References}

[1] S. S. Alam, Adoption of Internet in Malaysian SMEs, Journal of Small Business and Enterprise Development, 16 (2), 2009, pp. 240-255.

[2] S. S. Al-Gahtani, Computer Technology Acceptance Success Factors in Saudi Arabia: An Exploratory Study, Journal of Global Information Technology Management, 7 (1), 2004, pp. 529

[3] M. Bradford, J. Florin, Examining the role of innovation diffusion factors on the implementation success of Enterprise Resource Planning (ERP) systems, International Journal of Accounting Information Systems, 4(3), 2003, pp. 205-225.

[4] J. C. Brancheau, J. C. Wetherbe, The Adoption of Spreadsheet Software: Testing Innovation Diffusion Theory in the Context of End-User Computing. Information Systems Research, 1 (2), 1990, pp. 115-143.

[5] S. Bruque, J. Mayano, Organizational Determinants of Information Technology Adoption and Implementation in SMEs: The Case of Family and Cooperative Firms, Technovation, 27 (5), 2007, pp. 241-253.

[6] J. Carter, J. Franklin, T. Jambulingam, V. K. Gupta, N. Melone, Technological innovations: A Framework for Communicating Diffusion Effects, Information \& Management, 38 (5), 2001, pp. 277-287.

[7] S. C. H. Chan, E. W. T. Ngai, A Qualitative Study of Information Technology Adoption How Ten Organizations Adopted Web-Based Training, Information Systems Journal, 17 (3), 2007, pp. 289-315.

[8] P. Y. K. Chau, K. Y. Tam, Factors Affecting the Adoption of Open Systems: An Exploratory Study, MIS Quarterly, 21 (1), 1997, pp. 1-24.

[9] C. H. Cheng, W. Cheung, M. K. Chang, The Use of the Internet in Hong Kong: Manufacturing vs. Service, International Journal of Production Economics, 75 (1/2), 2002, pp. 33-45. 
[10] S. Chong, Electronic Commerce Adoption by Small and Medium Enterprises in Australia: An Empirical Study of Influencing Factors, [online] available at:

http://is2.lse.ac.uk/asp/aspecis/20040033.pdf [accessed February 2009].

[11] P. Chwelos, I. Benbasat, A. S. Dexter, Research Report: Empirical Test of an EDI Adoption Model, Information Systems Research, 12 (2), 2001, pp. 304-321.

[12] H. M. Cooper, L.V. Hedges, J. C. Valentine, The Hand book of Research Synthesis and Metaanalysis, $2^{\text {nd }}$ edition, Russell Sage Foundation, NY, 2009.

[13] R. B. Cooper, R. W. Zmud, Information Technology Implementation Research: A Technological Diffusion Approach, Management Science, 36 (2), 1990, pp. 123-139.

[14] P. B. Cragg, M. King, Small-Firm Computing: Motivators and Inhibitors, MIS Quarterly, 17 (1), 1993, pp. 47-60.

[15] H. Cramer, Mathematical method of statistics, Princeton University Press, 1999

[16] F. Damanpour, Innovation Type, Radicalness, and the Adoption Process, Communication Research, 15 (5), 1988, pp. 545-567.

[17] F. Damanpour, Organizational Innovation: A Meta-analysis of Effects of Determinants and Moderators, Academy of Management Journal, 34 (3), 1991, pp. 555-590.

[18] F. Damanpour, S. Gopalakrishnan, The Dynamics of the Adoption of Product and Process Innovations in Organizations, Journal of Management Studies, 38 (1), 2001, pp. 45-65.

[19] F. Damanpour, M. Schneider, Phases of the Adoption of Innovation in Organizations: Effects of Environment Organization and Top Managers, British Journal of Management, 17 (3), 2006, pp. 215-236.

[20] F. Damanpour, M. Schneider, Characteristics of Innovation and Innovation Adoption in Public Organizations: Assessing the Role of Managers, Journal of Public Administration Research \& Theory, 19 (3), 2009, pp. 495-522.

[21] F. Damanpour, J. D. Wischnevsky, Research on Organizational Innovation: Distinguishing Innovation-Generating from Innovation-Adopting Organizations, Journal of Engineering and Technology Management, 23 (4), 2006, pp. 269-91.

[22] DeVaus, Survey in Social Research, 5th edition, Routledge, 2002

[23] L. B. Eder, M. Igbaria, Magid; Determinants of Intranet Diffusion and Infusion, Omega, International Journal of Management Science, 29 (3), 2001, pp. 233-242.

[24] P. Ein-Dor, E. Segev, Strategic planning for Management Information Systems, Management Science, 24 (15), 1978, pp. 1631-1641.

[25] R. G. Fichman, The Role of Aggregation in the Measurement of IT-related Organizational Innovation, MIS Quarterly, 25 (4), 2001, pp. 427- 455

[26] R. G. Fichman, W. E. Carroll, The Diffusion and Assimilation of Information Technology Innovations R.W. Zmud (Ed.) Framing the Domains of IT Management: Projecting the Future...Through the Past, Cincinnati, OH: Pinnaflex Educational Resources, Inc. 1999.

[27] R. G. Fichman, C. F. Kemerer, The Assimilation of Software Process Innovations: An Organizational Learning Perspective, Management Science, 43 (10), 1997, pp. 1345-1363.

[28] K. Fletcher, G. Wright, C. Desai, The Role of Organizational Factors in the Adoption and Sophistication of Database Marketing in the UK Financial Services Industry Journal of Direct Marketing, 10 (1), 1996, pp. 10-21.

[29] G. V. Glass, B. McGaw, M. L. Smith, Meta-analysis in Social Research, Beverly Hills, CA: Sage, 1981. 
[30] E. Grandon, J. M. Pearson, E-commerce Adoption: Perception of Managers/Owners of Small and Medium Sized Firms in Chile, Communications of the Association for Information Systems, 13, 2004a, pp. 81-102.

[31] E. Grandon, J. M. Pearson, Electronic Commerce Adoption: An Empirical Study of Small and Medium US Businesses, Information \& Management, 42 (1), 2004b, pp. 197-216.

[32] V. Grover, M. D. Goslar, The Initiation, Adoption, and Implementation of Telecommunications Technologies in U.S. Organizations, Journal of Management Information Systems, 10 (1), 1993, pp. 141-163.

[33] L. V. Hedges, I. Olkin, Statistical Methods for Meta-analysis, Academic Press, Orlando, 1985

[34] J. E. Hunter, F. L. Schmidt, G. B. Jackson, Meta-analysis: Cumulating Research Findings across Studies, Beverly Hills, CA: Sage, 1982

[35] C. L. Iacovou, I. Benbasat, A. S. Dexter, Electronic Data Interchange and Small Organization: Adoption and Impact of Technology, MIS Quarterly, 19 (4), 1995, pp. 465-485.

[36] M. Igbaria, N. Zinatelli, P. Cragg, A. L. M. Cavaye, Personal Computing Acceptance Factors in Small Firms: A Structural Equation Model, MIS Quarterly, 21 (3), 1997, pp. 279-302.

[37] B. Y. Iskandar, S. Kurokawa, L. J. LeBlanc, Adoption of Electronic Data Interchange: The Role of Buyer-Supplier Relationships, IEEE Transaction on Engineering Management, 48 (4), 2001, pp. 505-517.

[38] B. N. Jeon, K. S. Han, M. J. Lee, Determining Factors for the Adoption of E-business the Case of SMEs in Korea, Applied Economics, 38 (16), 2006, pp. 1905-1916.

[39] T. Jing, T. Katherine, A. Manica, Business-to-Business Adoption of E-Commerce in China, Information \& Management, 44 (3), 2007, pp. 332-351.

[40] E. Karahanna, D. W. Straub, N. L. Chervany, Information Technology Adoption across Time: A Cross-sectional Comparison of Pre-adoption and Post-adoption Beliefs, MIS Quarterly, 23 (2), 1999, pp. 183-214.

[41] J. R. Kimberly, M. J. Evanisko, Organizational Innovation: The Influence of Individual Organizational and Contextual Factors on Hospital Adoption of Technological and Administrative Innovations, Academy of Management Journal, 24 (4), 1981, pp. 689-713.

[42] W. R. King, J. He, Understanding the Role and Methods of Meta-analysis in IS Research, Communications of the Association for Information Systems, 16, 2005, pp. 665-686.

[43] N. R. Kowtha, T. W. I. Choon, Determinants of Website Development: A Study of Electronic Commerce in Singapore, Information \& Management, 39 (3), 2001, pp. 227-242.

[44] K. K. Y. Kuan, P. Y. K. Chau, A Perception-Based Model for EDI Adoption in Small Businesses using a Technology-Organization-Environment Framework, Information \& Management, 38 (8), 2001, pp. 507-521.

[45] T. H. Kwon, R. W. Zmud, Unifying the Fragmented Models of Information Systems Implementation, in: J. R. Boland, R. Hirschheim (Eds.), Critical Issues in Information Systems Research, Wiley, New York, 1987, pp. 227-251.

[46] V. S. Lai, J. L. Guynes, An Assessment of the Influence of Organizational Characteristics on Information Technology Adoption Decision: A Discriminative Approach, IEEE Transaction on Engineering Management, 44 (2), 1997, pp. 146-157.

[47] C. C. H. Law, E. W. T. Ngai, ERP Systems Adoption: An Exploratory Study of the Organizational Factors and Impacts of ERP Success, Information \& Management, 44 (4), 2007, pp. 418-432. 
[48] G. Lee, W. Xia, Organizational Size and IT innovation Adoption: A Meta analysis, Information \& Management, 43 (8), 2006, pp. 975-985.

[49] C. Lertwongsatien, N. Wongpinunwatana, E-commerce Adoption in Thailand: An Empirical Study of Small and Medium Enterprises (SMEs), Journal of Global Information Technology Management, 6 (3), 2003, pp. 67-83.

[50] H. C. Looi, E- Commerce Adoption in Brunei Darussalam: A Quantitative Analysis of Factors Influencing its Adoption, Communications of the Association for Information Systems, 15, 2005, pp. 61-81.

[51] M. K. O. Lee, C. M. K. Cheung, Internet Retailing Adoption by Small-to-Medium Sized Enterprises (SMEs): A Multiple-Case Study, Information Systems Frontiers, 6 (4), 2004, pp. 385-397.

[52] J. Mehrtens, P. B. Cragg, M. M. Annette, A model of Internet Adoption by SMEs, Information \& Management, 39 (3), 2001, pp. 165-176.

[53] A. D. Meyer, J. B. Goes, Organizational Assimilation of Innovation: A Multilevel Contextual Analysis, Academy of Management Journal, 31 (4), 1988, pp. 897-923.

[54] D. A. Mirchandani, J. Motwani, Understanding Small Business Electronic Commerce Adoption: An Empirical Analysis, Journal of Computer Information Systems, 41 (3), 2001, pp. 70-73.

[55] M. K. Moch, E. V. Morse, Size, Centralization and Organizational Adoption of Innovations. American Sociological Review, 42 (5), 1977, pp. 716-725.

[56] W. Nie, D. L. Kollegg, How Process of Operations Management View Service Operations, Productions and Operations Management, 8 (3), 1999, pp. 339-355.

[57] P. C. Nystrom, K. Ramamurthy, A. L. Wilson, Organizational Context, Climate and Innovativeness: Adoption of Imaging Technology, Journal of Engineering and Technology Management, 19 (3/4), 2002, pp. 221-247.

[58] M. H. Olson, N. L. Chervany, The Relationship between Organizational Characteristics and the Structure of the Information Services Function, MIS Quarterly, 4 (2), 1980, pp. 57-68.

[59] G. Pervan, D. Bajwa, L. F. Lewis, A Study of the Adoption and Utilization of Seven Collaboration Technologies in Large Organizations in Australia and New Zealand, Journal of Global Information Technology Management, 8 (2), 2005, pp. 5-26.

[60] L. H. Peters, D. D. Hartke, J. T. Pohlmann, Fiedler's Contingency Theory of Leadership: An Application of the Meta-analysis Procedures of Schmidt and Hunter, Psychological Bulletin 97, 1985, pp. 274-285.

[61] C. Pollard, E-service Adoption and Use in Small Farms in Australia: Lessons Learned from a Government-Sponsored Programme, Journal of Global Information Technology Management, 6 (2), 2003, pp. 45-63.

[62] G. Premkumar, A Meta Analysis of Research on Information Technology Implementation in Small Business, Journal of Organizational Computing and Electronic Commerce, 13 (2), 2003, pp. 91-121.

[63] G. Premkumar, K. Ramamurthy, The role of inter-organizational and organizational factors on the decision mode for the adoption of Inter-organizational Systems, Decision Science; 26 (3), 1995, pp. 303-336.

[64] G. Premkumar, M. Roberts, Adoption of New Information Technologies in Rural Small Businesses, The International Journal of Management Science, 27 (4), 1999, pp. 467-484. 
[65] M. Quaddus, G. Hofmeyer, An Investigation into the Factors Influencing the Adoption of B2B Trading Exchanges in Small Businesses, European Journal of Information Systems, 16 (3), 2007, pp. 202-215.

[66] A. Rai, External Information Source and Channel Effectiveness and the Diffusion of CASE Innovations: An Empirical Study. European Journal of Information Systems, 4 (x), 1995, pp. 93-102.

[67] Rai, D. Bajwa, An Empirical Investigation into Factors Relating to the Adoption of Executive Information Systems (EIS): An Analysis of EIS for Collaboration and Decision Support, Decision Sciences, 28 (4), 1997, pp. 939-974.

[68] L. Raymond, Organizational Context and Information Systems Success: A Contingency Approach, Journal of Management Information Systems, 6 (4), 1990, pp.5-20.

[69] E. M. Rogers, F. Shoemaker, Communication of Innovations, New York: Free Press, 1971

[70] E. M. Rogers, Diffusion of Innovations, 3rd edition, Free Press, New York, 1983

[71] E. M. Rogers, Diffusion of Innovations, Free Press, New York, 1995

[72] R. Rosenthal, M. R. DiMatteo, Meta-analysis: Recent Developments in Qualitative Methods for Literature Reviews, Annual Review of Psychology, 52, 2001, pp. 58-82.

[73] B. Rye, J. R. Kimberly, The Adoption of Innovation by Provider Organizations in Health Care, Medical Care Research and Review, 64 (3), 2007, pp. 235-278.

[74] A. Scupola, The Adoption of Internet Commerce by SMEs in the South of Italy: An Environmental, Technological and Organizational perspective, Journal of Global Information Technology Management, 6 (1), 2003, pp. 52-71.

[75] H. Seyal, M. N. A. Rahman, A Preliminary Investigation of E-commerce Adoption in Small \& Medium Enterprises in Brunei, Journal of Global Information Technology Management, 6 (2), 2003, pp. 6-26.

[76] H. Seyal, M. N. A. Rahman, H. A. Y. H. A. Mohammad, A Quantitative Analysis of Factors Contributing Electronic Data Interchange Adoption among Bruneian SMEs, Business Process Management Journal, 13 (5), 2007, pp. 728-746.

[77] H. Seyal, M. M. Awais, S. Shamail, Andleeb, Determinants of Electronic Commerce in Pakistan: Preliminary Evidence from Small and Medium Enterprises, Electronic Markets, 14 (4), 2004, pp. 372-387.

[78] S. Sharma, A. Rai, An Assessment of the Relationship between ISD Leadership Characteristics and IS Innovation Adoption in Oorganizations, Information \& Management , 40 (5), 2003, pp. 391-401.

[79] K. S. Soliman, and B. D. Janz, An Exploratory Study to Identify the Critical Factors Affecting the Decision to Establish Internet Based Inter-organizational Information Systems, Information \& Management, 41 (6), 2004, pp. 697-706.

[80] P. P. Soh, C. S. Yap, K. S. Raman, Impact of Consultants on Computerization Success in Small Businesses, Information and Management, 22 (5), 1992, pp. 309-319.

[81] A. Subramanian, S. Nilakanta, Organizational Innovativeness: Exploring the Relationship between Organizational Determinants of Innovation, Types of Innovations, and Measures of Organizational Performance, Omega, International Journal Management Science, 24 (6), 1996, pp. 631-647.

[82] J. Tan, K. Tyler, A. Manica, Business-to-Business Adoption of E-Commerce in China, Information \& Management, 44 (3), 2007, pp. 332-351. 
[83] S. Tang, An Impact Factor Model of Intranet Adoption: An Exploratory and Empirical Research, Journal of Systems and Software, 51 (3), 2000, pp. 157-173.

[84] T. S. H. Teo, C. Ranganathan, Adopters and Non-adopters of Business to Business Electronic Commerce in Singapore, Information \& Management, 42 (1), 2004, pp. 89-102.

[85] T. S. H. Teo, S. Lin, K. Lai, Adopters and Non-adopters of E-procurement in Singapore: An empirical Study, Omega, International Journal Management Science, 37 (5), 2009, pp. 972-987.

[86] J. Y. L. Thong, An Integrated Model of Information Systems Adoption in Small Businesses, Journal of Management Information Systems, 15 (4), 1999, pp. 187-214.

[87] J. Y. L. Thong, C. Yap, CEO Characteristics, Organizational Characteristics and Information Technology Adoption in Small Businesses, Omega, International Journal of Management Science, 23 (4), 1995, pp. 429-442.

[88] J. Y. L. Thong, C. Yap, K. S. Raman, Top Management Support in Small Business Information Systems Implementation: How Important is it?, Proceedings of the 1993 Conference on Computer Personnel Research, St Louis, Missouri, United States, 1993, pp. 416-425.

[89] L. G. Tornatzky, M. Fleischer, The Process of Technological Innovation, Lexington Books, 1990

[90] L. G. Tornatzky, K. Klein, Innovation Characteristics and Innovation Adoption Implementation: A Meta-analysis of Findings, IEEE Transactions on Engineering Management, 29 (1), 1982, pp. 28-45.

[91] H. Tsao, K. H. C. Lin, C. Lin, An Investigation of Critical Success Factors in the Adoption of B2BEC by Taiwanese Companies, The Journal of American Academy of Business, Cambridge, 2004

[92] J. M. Utterback, W. J. Abernathy, A Dynamic Model of Process and Product Innovation, Omega, International Journal of Management Science, 3 (6), 1975, pp. 639-656.

[93] Y. C. W. Wang, C. Chang, M. S. H. Heng, The Level of Information Technology Adoption, Business Network, and a Strategic Position Model for Evaluating Supply Chain Integration, Journal of Electronic Commerce Research, 5 (2); 2004, pp. 85-98.

[94] S. Wang, W. Cheung, E-Business Adoption by Travel Agencies: Prime Candidates for Mobile E-business, International Journal of Electronic Commerce, 8 (3), 2004, pp. 43-63.

[95] R. A. Wolfe, Organizational Innovation: Review, Critque, and Suggested Research Directions. Journal of Management Studies, 31 (3), 1994, pp. 405-431.

[96] G. Zaltman, R. Duncan, J. Holbek, Innovations and Organizations, Wiley, New York, 1973

[97] K. Zhu, D. Shutao, S. Xin-Xu, K. L. Kraemer, Innovation Diffusion in Global Contexts: Determinants of Post-adoption Digital Transformation of European Companies, European Journal of Information Systems, 15 (6), 2006a, pp. 601-616.

[98] K. Zhu, K. L. Kraemer, S. Xin-Xu, The Process of Innovation Assimilation by Firms in Different Countries: A Technology Diffusion Perspective on E-Business, Management Science, 52 (10), 2006b, pp. 1557-1576.

[99] R. W. Zmud, Diffusion of Modern Software Practices: Influence of Centralization and Formalization. Management Science, 28 (12), 1982, pp. 1421-1431. 


\section{Appendix}

\begin{tabular}{|c|c|c|c|c|c|c|c|c|c|c|c|c|c|c|c|c|c|}
\hline Study & Innovation & $\begin{array}{l}\text { STG } \\
\text { ADP }\end{array}$ & $\begin{array}{l}\text { SAM } \\
\text { SIZE }\end{array}$ & $\begin{array}{l}\text { TYP } \\
\text { INO }\end{array}$ & $\begin{array}{l}\text { ORG } \\
\text { CAT }\end{array}$ & $\begin{array}{l}\text { IND } \\
\text { TYP }\end{array}$ & $\begin{array}{l}\text { ANA } \\
\end{array}$ & $\begin{aligned} \text { ORS } \\
\end{aligned}$ & ITE & TMS & RSC & IDS & IIF & FOR & CEN & ORE & $\mathbf{P C H}$ \\
\hline & & & & & & & & $\overline{S \mathrm{CRV}}$ & S CRV & S CRV & S CRV & S CRV & S CRV & S CRV & $\mathrm{S}$ CRV & S CRV & S CRV \\
\hline $\begin{array}{l}\operatorname{Alam}(2005) \\
\end{array}$ & Internet & ADP & 368 & PRD & SML & MIX & COR & & $\begin{array}{lll}\text { P } & 0.741 \\
\end{array}$ & & & & & & & & \\
\hline \multirow[t]{2}{*}{$\overline{\text { Al-Gahtani (2004) }}$} & 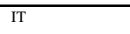 & $\overline{A D P}$ & 1190 & PRC & $\begin{array}{l}\text { MIX } \\
\end{array}$ & MIX & $\mathrm{COR}$ & & & & $\begin{array}{llll}\text { P } & 0.320\end{array}$ & & & & & & \\
\hline & & IMP & 1190 & PRC & MIX & MIX & COR & & & & $\begin{array}{lll}\text { P } 0.484 & \end{array}$ & & & & & & \\
\hline Bradford \& Florin (2003) & ERP & IMP & 51 & PRD & LRG & $\mathrm{MFG}$ & $\mathrm{COR}$ & & & $\begin{array}{l}\text { P } 0.4711 \\
\end{array}$ & & & & $\begin{array}{ll}\text { P } 0.477 \\
\end{array}$ & & & \\
\hline \multirow[t]{2}{*}{ Bruque \& Mayano (2007) } & 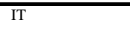 & ADP & 15 & PRC & $\begin{array}{l}\text { SML } \\
\end{array}$ & MIX & DES & $P$ & & $P$ & & & & $P$ & & & $P$ \\
\hline & & IMP & 15 & PRC & SML & MIX & DES & & & $\mathrm{P}$ & & & & & & & \\
\hline Chan \& Ngai (2007) & $\begin{array}{l}\text { Internet } \\
\end{array}$ & ADP & 10 & PRD & MIX & MIX & DES & $\mathrm{N}$ & & & $\mathrm{N}$ & & $P$ & & & & $P$ \\
\hline Chau \& Tam (1997) & $\begin{array}{l}\text { Open System } \\
\end{array}$ & ADP & 89 & PRD & MIX & MIX & $\begin{array}{c}\mathrm{REG} \\
\mathrm{REG}\end{array}$ & & & & & & $\mathrm{N}$ & $\mathrm{N}$ & & & \\
\hline $\begin{array}{l}\text { Chong (2004) } \\
\end{array}$ & E-Commerce & ADP & 115 & 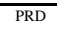 & $\begin{array}{ll}\text { SML } \\
\end{array}$ & $\begin{array}{c}\text { MIX } \\
\end{array}$ & 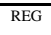 & $\mathrm{N}$ & & $\mathrm{N}$ & & & & & & $\bar{N}$ & \\
\hline Chwelos et al. (2001) & EDI & $\overline{\mathrm{ADP}}$ & 317 & PRD & MIX & MIX & $\mathrm{COR}$ & & & & & & $\begin{array}{l}\text { P } 0.308 \\
\end{array}$ & & & & \\
\hline $\begin{array}{l}\text { Cragg \& King (1993) } \\
\end{array}$ & Computing & IMP & 6 & PRC & $\begin{array}{c}\text { SML } \\
\end{array}$ & $\overline{\mathrm{MFG}}$ & DES & & P & & & & & & & & \\
\hline \multirow{3}{*}{$\begin{array}{l}\text { Damanpour \& Schneider } \\
\text { (2006) }\end{array}$} & IT & \begin{tabular}{l|l|l|l} 
INI \\
\end{tabular} & 1276 & PRC & MIX & MIX & $\mathrm{COR}$ & $\begin{array}{ll}\text { P } 0.270 \\
\end{array}$ & & & P 0.110 & & & & & & \\
\hline & & ADP & 1276 & PRC & MIX & MIX & COR & P 0.260 & & & P 0.170 & & & & & & \\
\hline & & IMP & 1276 & PRC & MIX & MIX & COR & P 0.250 & & & P 0.140 & & & & & & \\
\hline $\begin{array}{l}\text { Damanpour \& Schneider } \\
(2009)\end{array}$ & IT & ADP & 725 & PRC & MIX & 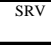 & COR & $\begin{array}{lll}\text { P } 0.270 & \end{array}$ & & & $\begin{array}{lll}\text { P } 0.130 & \\
\end{array}$ & & & & & & \\
\hline \multirow[t]{2}{*}{ Eder \& Igbaria (2001) } & $\begin{array}{l}\text { Intranet } \\
\end{array}$ & ADP & 281 & 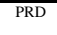 & $\begin{array}{l}\text { LRG } \\
\end{array}$ & MIX & $\mathrm{COR}$ & $\begin{array}{ll}P \quad 0.030 \\
\end{array}$ & & P 0.260 & & & $\begin{array}{l}\mathrm{N}-0.050 \\
\end{array}$ & $\begin{array}{l}\mathrm{N} 0.100 \\
\end{array}$ & $\begin{array}{ll}\mathrm{N} 0.090 \\
\end{array}$ & & \\
\hline & & IMP & 281 & PRD & LRG & MIX & COR & N 0.070 & & P 0.370 & & & P -0.010 & $\mathrm{~N} 0.150$ & N 0.080 & & \\
\hline \multirow[t]{7}{*}{ Fichman (2001) } & OO Programming & ADP & 608 & PRD & MIX & MIX & $\mathrm{COR}$ & & $\begin{array}{ll}\text { P } 0.270 \\
\end{array}$ & & & $\begin{array}{ll}\text { P } 0.280 \\
\end{array}$ & & & & & \\
\hline & OO Programming & IMP & 608 & PRD & MIX & MIX & COR & & P 0.340 & & & P 0.330 & & & & & \\
\hline & OO Programming & MIX & 608 & PRD & MIX & MIX & COR & & P 0.330 & & & P 0.360 & & & & & \\
\hline & Relational DMS & MIX & 608 & PRD & MIX & MIX & COR & & N 0.030 & & & P 0.390 & & & & & \\
\hline & CASE & MIX & 608 & PRD & MIX & MIX & COR & & $\mathrm{N}-0.010$ & & & P 0.440 & & & & & \\
\hline & Software Process & ADP & 608 & PRD & MIX & MIX & COR & & $\begin{array}{ll}\text { P } 0.140 \\
-140\end{array}$ & & & P 0.550 & & & & & \\
\hline & Software Process & MIX & 608 & PRD & MIX & MIX & COR & & P 0.170 & & & P 0.570 & & & & & \\
\hline $\begin{array}{l}\text { Fletcher et al. (1996) } \\
\end{array}$ & $\begin{array}{c}\text { Database } \\
\text { Dase }\end{array}$ & MIX & 86 & $\begin{array}{l}\text { PRD } \\
\end{array}$ & LRG & 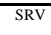 & $\mathrm{COR}$ & $P-0.060$ & & & $\begin{array}{ll}\text { P } 0.209 \\
\end{array}$ & & & $\begin{array}{lll} & 0.147 \\
\end{array}$ & $\begin{array}{c}\mathrm{N}-0.142 \\
\end{array}$ & & \\
\hline Grandon \& Pearson (2004a) & E-Commerce & ADP & 83 & PRD & $\begin{array}{c}\text { SML } \\
\end{array}$ & MIX & DIS & & & $\mathrm{N}$ & & & & & & P & \\
\hline 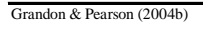 & E-commerce & ADP & 100 & PRD & SML & MIX & OTH & & & $\mathrm{P}$ & & & & & & $\mathrm{P}$ & \\
\hline \multirow[t]{3}{*}{ Grover \& Goslar (1993) } & $\begin{array}{l}\text { Telecommunicatio } \\
\mathrm{n} \text { Technologies }\end{array}$ & $\begin{array}{ll}\text { INI } \\
\end{array}$ & 154 & $\begin{array}{l}\text { PRD } \\
\end{array}$ & MIX & MIX & REG & $\mathrm{N}$ & & & & & & $\mathrm{N}$ & P & & \\
\hline & & ADP & 154 & PRD & MIX & MIX & REG & $\mathrm{N}$ & & & & & & $\mathrm{N}$ & $\mathrm{P}$ & & \\
\hline & & IMP & 154 & PRD & MIX & MIX & REG & $\mathrm{N}$ & & & & & & $\mathrm{N}$ & P & & \\
\hline \multirow[t]{2}{*}{ Iacovou et al. (1995) } & EDI & ADP & 7 & $\begin{array}{l}\text { PRD } \\
\end{array}$ & SML & MIX & DES & & & & & & & & & $P$ & \\
\hline & & IMP & 7 & PRD & SML & MIX & DES & & & & & & & & & P & \\
\hline Igbaria et al. (1994) & IT & $\begin{array}{l}\mathrm{IMP} \\
\mathrm{M}\end{array}$ & 358 & PRC & $\begin{array}{c}\text { SML } \\
\end{array}$ & MFG & $\mathrm{COR}$ & & & P 0.200 & & & & & & & \\
\hline \multirow[t]{2}{*}{ Iskandar et al. (2001) } & EDI & $\begin{array}{l}\mathrm{ADP} \\
\mathrm{A}\end{array}$ & 111 & $\begin{array}{l}\text { PRD } \\
\end{array}$ & MIX & 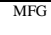 & $\mathrm{COR}$ & N 0.217 & N 0.155 & & & & & & & & \\
\hline & & IMP & 111 & PRD & MIX & MFG & COR & P 0.394 & N 0.189 & & & & & & & & \\
\hline Jeon et al. (2006) & $\begin{array}{l}\text { E-business } \\
\end{array}$ & $\overline{A D P}$ & 204 & PRD & $\begin{array}{c}\text { SML } \\
\end{array}$ & MIX & $\mathrm{COR}$ & $\begin{array}{ll}\mathrm{N} 0.050 \\
\end{array}$ & $\begin{array}{l}\mathrm{P} 0.420 \\
\end{array}$ & & & & & & & & \\
\hline \multirow[t]{2}{*}{ Karahanna et al. (1999) } & IT & ADP & 77 & PRD & MIX & MIX & PLS & & & $\mathrm{P}$ & & & $\bar{P}$ & & & & \\
\hline & & IMP & 153 & PRD & MIX & MIX & PLS & & & $\mathrm{P}$ & & & $\mathrm{N}$ & & & & \\
\hline Kowtha \& Choon (2001) & E-Commerce & ADP & 135 & PRD & MIX & SRV & COR & & $\begin{array}{l}\text { P } 0.530 \\
\end{array}$ & & & & & & & & \\
\hline $\begin{array}{l}\text { Kuan \& Chau (2001) } \\
\end{array}$ & EDI & ADP & 525 & PRD & SML & MIX & $\begin{array}{l}\text { REG } \\
\end{array}$ & & $P$ & & & & & & & & \\
\hline $\begin{array}{l}\text { Lai \& Guynes (1997) } \\
\end{array}$ & ISDN & $\frac{\mathrm{INI}}{\mathrm{IN}}$ & 161 & PRD & LRG & MIX & DIS & $P$ & & & P & & & $\mathrm{N}$ & $\mathrm{N}$ & & \\
\hline $\begin{array}{l}\text { Law \& Ngai (2007) } \\
\end{array}$ & ERP & ADP & 96 & 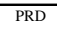 & MIX & MIX & $\begin{array}{l}\text { OTH } \\
\text { OT }\end{array}$ & & & $\mathrm{N}$ & & & & & & & \\
\hline Lee \& Cheung (2004) & Internet & ADP & 3 & PRD & SML & SRV & DES & & $P$ & & & & & & & $\mathrm{P}$ & \\
\hline $\begin{array}{l}\text { Lertwongsatien \& } \\
\text { Wongpinumwatana (2003) }\end{array}$ & E-commerce & ADP & 386 & $\begin{array}{l}\text { PRD } \\
\end{array}$ & SML & MIX & ОTH & $\mathrm{N}$ & $\mathrm{P}$ & $\mathrm{P}$ & & & & & & & \\
\hline $\begin{array}{l}\text { Looi (2005) } \\
\end{array}$ & E-Commerce & $\overline{\mathrm{ADP}}$ & 184 & 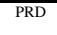 & $\begin{array}{l}\text { SML } \\
\end{array}$ & MIX & $\mathrm{COR}$ & & P 0.556 & & & & & & & & \\
\hline $\begin{array}{l}\text { Mehrtens et al. (2001) } \\
\end{array}$ & Internet & ADP & 5 & PRD & SML & SRV & DES & & & & & & & & & P & \\
\hline
\end{tabular}




\begin{tabular}{|c|c|c|c|c|c|c|c|c|c|c|c|c|c|c|c|c|c|c|c|c|c|c|c|c|c|}
\hline \multirow[t]{2}{*}{ Study } & \multirow[t]{2}{*}{ Innovation } & \multirow{2}{*}{$\begin{array}{l}\text { STG } \\
\text { ADP }\end{array}$} & \multirow{2}{*}{$\begin{array}{l}\text { SAM } \\
\text { SIZE }\end{array}$} & \multirow{2}{*}{$\begin{array}{l}\text { TYP } \\
\text { INO }\end{array}$} & \multirow{2}{*}{$\begin{array}{l}\text { ORG } \\
\text { CAT }\end{array}$} & \multirow{2}{*}{$\begin{array}{l}\text { IND } \\
\text { TYP }\end{array}$} & \multirow{2}{*}{ ANA } & \multicolumn{2}{|c|}{ ORS } & \multicolumn{2}{|c|}{ ITE } & \multicolumn{2}{|c|}{ TMS } & \multicolumn{2}{|c|}{ RSC } & \multicolumn{2}{|r|}{ IDS } & & IIIF & & FOR & & CEN & ORE & PCH \\
\hline & & & & & & & & $\bar{s}$ & CRV & $\mathbf{s}$ & CRV & $\mathbf{S}$ & CRV & $\mathbf{S}$ & CRV & $\mathbf{S}$ & CRV & $\mathrm{s}$ & CRV & $\mathrm{s}$ & CRV & S & CRV & S CRV & S CRV \\
\hline $\begin{array}{l}\text { Mirchandani \& Motwani } \\
\text { (2001) }\end{array}$ & E-Commerce & ADP & 62 & PRD & SML & MIX & $\mathrm{COR}$ & & & $P$ & 0.715 & & & & & & & & & & & & & & \\
\hline Nystrom et al. (2002) & $\begin{array}{l}\text { Imaging } \\
\text { Technology }\end{array}$ & ADP & 70 & PRD & LRG & SRV & COR & $P$ & 0.570 & & & & & $P$ & 0.310 & & & & & & & & & & \\
\hline Pervan et al. (2005) & $\begin{array}{l}\text { Collaboration } \\
\text { Technologies }\end{array}$ & INI & 82 & PRD & LRG & MIX & $\mathrm{COR}$ & & & & & & & & & $\mathrm{P}$ & 0.300 & & & & & $\mathrm{P}$ & & & \\
\hline & (Email) & ADP & 82 & PRD & LRG & MIX & $\mathrm{COR}$ & & & & & & & & & $\mathrm{P}$ & 0.220 & & & & & $\mathrm{~N}$ & & & \\
\hline & & IMP & 82 & PRD & LRG & MIX & COR & & & & & & & & & $\mathrm{P}$ & 0.240 & & & & & $\mathrm{~N}$ & & & \\
\hline$\overline{P o l l a r d ~(2003)}$ & $\begin{array}{l}\text { E-Service } \\
\end{array}$ & $\begin{array}{ll}\mathrm{IMP} \\
\end{array}$ & 30 & PRD & SML & $\begin{array}{c}\mathrm{MFG} \\
\end{array}$ & OTH & & & $\mathrm{P}$ & & & & & & & & & & & & & & & \\
\hline $\begin{array}{l}\text { Premkumar \& Ramamurthy } \\
\text { (1995) }\end{array}$ & $\begin{array}{l}\text { (Inter- } \\
\text { organizational }\end{array}$ & ADP & 201 & MIX & MIX & MIX & $\mathrm{COR}$ & & & & & $\mathrm{P}$ & 0.275 & & & & & N 0 & 0.123 & & & & & & N 0.074 \\
\hline & Systems) EDI & IMP & 201 & MIX & MIX & MIX & $\mathrm{COR}$ & & & & & $\mathrm{N}$ & 0.178 & & & & & $\mathrm{P} 0$ & 0.210 & & & & & & N -0.040 \\
\hline Premkumar \& Roberts (1999) & Email & ADP & 78 & PRD & SML & MIX & DIS & $P$ & & $\mathrm{~N}$ & & $P$ & & & & & & & & & & & & & \\
\hline & $\begin{array}{l}\text { On-line Data } \\
\text { Access }\end{array}$ & ADP & 78 & PRD & SML & MIX & DIS & $\mathrm{P}$ & & $\mathrm{P}$ & & $\mathrm{P}$ & & & & & & & & & & & & & \\
\hline & Internet Access & ADP & 78 & PRD & SML & MIX & DIS & $\mathrm{P}$ & & $\mathrm{N}$ & & $\mathrm{N}$ & & & & & & & & & & & & & \\
\hline & EDI & ADP & 78 & PRD & SML & MIX & DIS & $\mathrm{N}$ & & $\mathrm{N}$ & & $\mathrm{P}$ & & & & & & & & & & & & & \\
\hline Premkumar (2003) & $\begin{array}{l}\text { Communication } \\
\text { Technologies }\end{array}$ & ADP & 207 & PRD & SML & MIX & REG & $P$ & & & & $P$ & & & & & & & & & & & & & \\
\hline Quaddus \& Hofmeyer (2007) & E-commerce & INI & 211 & PRD & SML & MIX & OTH & & & & & & & & & & & & & & & & & $\mathrm{N}$ & \\
\hline Rai \& Bajwa (1997) & $\begin{array}{l}\text { Executive } \\
\text { Information }\end{array}$ & ADP & 210 & PRD & MIX & MIX & $\mathrm{COR}$ & & & & & & & & & $\mathrm{N}$ & & & & & & & & & \\
\hline & $\begin{array}{l}\text { System } \\
\text { (Collaboration) }\end{array}$ & IMP & 210 & PRD & MIX & MIX & $\mathrm{COR}$ & & & & & $\mathrm{P}$ & 0.290 & & & $\mathrm{P}$ & & & & & & & & & \\
\hline & $\begin{array}{l}\text { Executive } \\
\text { Information }\end{array}$ & ADP & 210 & PRD & MIX & MIX & $\mathrm{COR}$ & $\mathrm{P}$ & 0.280 & & & & & & & $\mathrm{P}$ & 0.330 & & & & & & & & \\
\hline & $\begin{array}{l}\text { System (Decision } \\
\text { Support) }\end{array}$ & IMP & 210 & PRD & MIX & MIX & $\mathrm{COR}$ & & & & & $\mathrm{P}$ & 0.220 & & & $\mathrm{P}$ & 0.330 & & & & & & & & \\
\hline Raymond (1990) & $\begin{array}{l}\text { Information } \\
\text { Systems }\end{array}$ & IMP & 34 & PRC & MIX & MFG & $\mathrm{COR}$ & $\mathrm{P}$ & 0.310 & $\mathrm{P}$ & 0.500 & & & $\mathrm{~N}$ & 0.000 & & & & & & & & & & \\
\hline & $\begin{array}{l}\text { Information } \\
\text { Systems (Off-line) }\end{array}$ & IMP & 34 & PRC & MIX & MFG & COR & $\mathrm{N}$ & -0.020 & $\mathrm{P}$ & 0.370 & & & $\mathrm{~N}$ & 0.180 & & & & & & & & & & \\
\hline & $\begin{array}{l}\text { Information } \\
\text { Systems (On-line) }\end{array}$ & IMP & 34 & PRC & MIX & MFG & $\mathrm{COR}$ & $\mathrm{P}$ & 0.310 & $\mathrm{P}$ & 0.190 & & & $\mathrm{~N}$ & -0.110 & & & & & & & & & & \\
\hline Scupola (2003) & E-commerce & ADP & 7 & PRD & SML & MIX & DES & $\mathrm{N}$ & & $P$ & & & & $\mathrm{~N}$ & & & & $\mathrm{P}$ & & & & & & & $\mathrm{P}$ \\
\hline & & IMP & 7 & PRD & SML & MIX & DES & $\mathrm{N}$ & & $\mathrm{P}$ & & & & $\mathrm{N}$ & & & & $\mathrm{P}$ & & & & & & & $\mathrm{P}$ \\
\hline Seyal \& Rahman (2003) & E-Commerce & ADP & 95 & PRD & SML & MIX & $\mathrm{COR}$ & $\mathrm{N}$ & -0.190 & 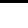 & & $P$ & 0.350 & & & & & & & & & & & & \\
\hline Seyal et al. (2004) & E-Commerce & ADP & 54 & PRD & SML & MIX & $\mathrm{COR}$ & & & & & $\mathrm{N}$ & 0.076 & & & & & & & & & & & & \\
\hline Seyal et al. (2007) & EDI & ADP & 50 & PRD & SML & MIX & $\mathrm{COR}$ & & & & & $\mathrm{P}$ & 0.311 & & & & & & & & & & & & \\
\hline Sharma \& Rai (2002) & CASE & ADP & 350 & PRD & MIX & $\begin{array}{l}\text { MIX } \\
\end{array}$ & DIS & & & & & & & & & $\mathrm{P}$ & & & & & & & & & \\
\hline Soliman \& Janz (2004) & $\begin{array}{l}\text { Inter- } \\
\text { organizational } \\
\text { Information } \\
\text { Systems }\end{array}$ & ADP & 87 & PRC & MIX & MIX & OTH & & & & & $\mathrm{P}$ & & & & & & & & & & & & & \\
\hline $\begin{array}{l}\text { Subramanian \& Nilakanta } \\
\text { (1996) }\end{array}$ & $\begin{array}{l}\text { Technical } \\
\text { Innovation } \\
\text { (Mean) }\end{array}$ & ADP & 141 & PRC & LRG & SRV & $\mathrm{COR}$ & $\mathrm{N}$ & -0.090 & & & & & $\mathrm{P}$ & 0.310 & & & & & $\mathrm{~N}$ & 0.140 & $\mathrm{P}$ & -0.290 & & \\
\hline & $\begin{array}{l}\text { Technical } \\
\text { Innovation (Time) }\end{array}$ & ADP & 141 & PRC & LRG & SRV & $\mathrm{COR}$ & $\mathrm{P}$ & 0.340 & & & & & $\mathrm{P}$ & 0.400 & & & & & $\mathrm{~N}$ & -0.010 & $\mathrm{P}$ & -0.320 & & \\
\hline & $\begin{array}{l}\text { Technical } \\
\text { Innovation } \\
\text { (Consistency) }\end{array}$ & ADP & 141 & PRC & LRG & SRV & $\mathrm{COR}$ & $\mathrm{N}$ & 0.020 & & & & & $\mathrm{P}$ & -0.280 & & & & & $\mathrm{~N}$ & 0.060 & $\mathrm{~N}$ & 0.130 & & \\
\hline & $\begin{array}{l}\text { Administrative } \\
\text { Innovation } \\
\text { (Mean) }\end{array}$ & ADP & 141 & PRC & LRG & SRV & $\mathrm{COR}$ & $\mathrm{P}$ & 0.230 & & & & & $\mathrm{P}$ & -0.170 & & & & & $\mathrm{P}$ & 0.330 & $\mathrm{~N}$ & -0.100 & & \\
\hline & $\begin{array}{l}\text { Adminisistrative } \\
\text { Innovation (Time) }\end{array}$ & ADP & 141 & PRC & LRG & SRV & $\mathrm{COR}$ & $\mathrm{P}$ & 0.170 & & & & & $\mathrm{~N}$ & -0.040 & & & & & $\mathrm{~N}$ & 0.090 & $\mathrm{P}$ & 0.390 & & \\
\hline & $\begin{array}{l}\text { Administrative } \\
\text { Innovation } \\
\text { (Consistency) }\end{array}$ & ADP & 141 & PRC & LRG & SRV & $\mathrm{COR}$ & $\mathrm{N}$ & 0.040 & & & & & $\mathrm{~N}$ & -0.020 & & & & & $\mathrm{P}$ & -0.350 & $\mathrm{P}$ & -0.370 & & \\
\hline Tan et al. (2007) & E-Commerce & ADP & 134 & PRD & MIX & MIX & DIS & & & & & & & & & & & & & & & & & $\mathrm{P}$ & \\
\hline & & IMP & 134 & PRD & MIX & MIX & DIS & & & & & & & & & & & & & & & & & $\mathrm{P}$ & \\
\hline Tang (1997) & Intranet & ADP & 190 & PRD & MIX & MIX & OTH & & & & & $\mathrm{P}$ & & & & & & & & & & & & & \\
\hline Teo \& Ranganathan (2004) & E-Commerce & ADP & 108 & PRD & MIX & MIX & OTH & & & $\mathrm{P}$ & & $\mathrm{P}$ & & & & & & & & $\mathrm{P}$ & & & & & $\mathrm{P}$ \\
\hline Teo et al. (2009) & E-procurement & ADP & 141 & PRD & LRG & MIX & $\begin{array}{ll}\mathrm{COR} \\
\mathrm{COR}\end{array}$ & $P$ & 0.310 & & & $\mathrm{P}$ & 0.340 & & & & & & & & & & & & \\
\hline Thong \& Yap (1995) & IT & ADP & 166 & MIX & SML & MIX & $\mathrm{COR}$ & $P$ & 0.272 & & & & & & & & & & & & & & & & \\
\hline Thong (1999) & IT & ADP & 294 & MIX & SML & MIX & COR & $P$ & 0.364 & $\mathrm{P}$ & 0.286 & & & & & & & & & & & & & & \\
\hline & & IMP & 294 & MIX & SML & MIX & $\mathrm{COR}$ & $\mathrm{P}$ & 0.472 & $\mathrm{P}$ & 0.398 & & & & & & & & & & & & & & \\
\hline Thong et al. (1996) & IT & IMP & 114 & PRC & SML & MIX & OTH & & & & & $\mathrm{N}$ & & & & & & & & & & & & & \\
\hline Tsao et al. (2004) & E-Commerce & ADP & 72 & PRD & SML & MIX & COR & & & & & $P$ & 0.659 & & & & & & & & & & & $\begin{array}{lll}\text { P } & 0.7\end{array}$ & \\
\hline
\end{tabular}




\begin{tabular}{|c|c|c|c|c|c|c|c|c|c|c|c|c|c|c|c|c|c|c|c|}
\hline \multirow[t]{2}{*}{$\begin{array}{l}\text { Study } \\
\end{array}$} & \multirow[t]{2}{*}{$\begin{array}{l}\text { Innovation } \\
\end{array}$} & \multirow{2}{*}{$\begin{array}{l}\text { STG } \\
\text { ADP }\end{array}$} & \multirow{2}{*}{$\begin{array}{l}\text { SAM } \\
\text { SIZE }\end{array}$} & \multirow{2}{*}{$\begin{array}{l}\text { TYP } \\
\text { INO }\end{array}$} & \multirow{2}{*}{$\begin{array}{l}\text { ORG } \\
\text { CAT }\end{array}$} & \multirow{2}{*}{$\begin{array}{l}\text { IND } \\
\text { TYP }\end{array}$} & \multirow[t]{2}{*}{$\overline{\text { ANA }}$} & \multicolumn{2}{|c|}{ ORS } & \multirow{2}{*}{$\begin{array}{c}\text { ITE } \\
\mathrm{S} \text { CRV }\end{array}$} & \multirow{2}{*}{\begin{tabular}{l}
\multicolumn{2}{|c|}{ TMS } \\
S $\quad$ CRV
\end{tabular}} & \multirow{2}{*}{$\begin{array}{r}\text { RSC } \\
S \mathrm{CR} \\
\end{array}$} & \multirow{2}{*}{ 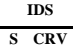 } & \multirow{2}{*}{\multicolumn{2}{|c|}{$\begin{array}{c}\text { IIF } \\
\text { S CRV }\end{array}$}} & \multirow{2}{*}{$\begin{array}{c}\text { FOR } \\
\text { S CRV }\end{array}$} & \multirow{2}{*}{$\begin{array}{c}\text { CEN } \\
\text { S CRV }\end{array}$} & \multirow{2}{*}{\begin{tabular}{c}
\multicolumn{2}{c}{ ORE } \\
S CRV
\end{tabular}} & \multirow{2}{*}{\begin{tabular}{c}
\multicolumn{2}{c}{ PCH } \\
S $\mathrm{CRVV}$
\end{tabular}} \\
\hline & & & & & & & & & $\overline{\mathrm{CRV}}$ & & & & & & & & & & \\
\hline \multirow[t]{2}{*}{ Wang \& Cheung (2004) } & E-Business & $\overline{\mathrm{ADP}}$ & 137 & $\begin{array}{l}\text { PRD } \\
\end{array}$ & $\begin{array}{l}\text { SML } \\
\end{array}$ & SRV & $\mathrm{COR}$ & & & & & $\begin{array}{lll}\mathrm{N} & 0.12 \\
\end{array}$ & & $P$ & 0.450 & & & & \\
\hline & & IMP & 137 & PRD & SML & SRV & $\mathrm{COR}$ & & & & & P 0.33 & & $P$ & 0.460 & & & & \\
\hline Wang et al. (2004) & E-business & MIX & 121 & PRD & MIX & MIX & COR & $\begin{array}{lll}\text { P } & 0.4\end{array}$ & 0.450 & & & & & & & & & $\begin{array}{lll}\text { P } & 0.663\end{array}$ & \\
\hline Zhu et al. (2006a) & E-Business & IMP & 1415 & PRC & MIX & MIX & PLS & $P$ & & $P$ & & & & & & & & & \\
\hline \multirow[t]{3}{*}{ Zhu et al. (2006b) } & E-business & INI & 1857 & PRD & MIX & MIX & COR & $\begin{array}{lll} & 0.1\end{array}$ & 0.110 & & & & & $\mathrm{P}$ & 0.220 & & & & \\
\hline & & ADP & 1857 & PRD & MIX & MIX & $\mathrm{COR}$ & $\begin{array}{ll}\text { P } & 0.1\end{array}$ & .120 & & & & & $\mathrm{P}$ & 0.320 & & & & \\
\hline & & IMP & 1857 & PRD & MIX & MIX & $\mathrm{COR}$ & P 0.0 & .050 & & & & & $P$ &. .40 & & & & \\
\hline
\end{tabular}

Stage of Adoption - STG ADP, Initiation - INI, Adoption - ADP, Implementation - IMP, Mixed - MIX $\quad$ Sample Size - SAM SIZE Type of Innovation - TYP INO, Product - PRD, Process - PRC, Mixed - MIX Organization Category - ORG CAT, Lareg - LRG, Small - SML, Mixed - MIX Industry Type - IND TYP, Manufacturing - MFG, Service - SRV, Mixed - MIX

Analysis - ANA, Correlation - COR, Regression - REG, Discriminant - DIS, Descriptive - DES, PLS - PLS, Other - OTH

Organizational Characteristics - Organizational size - ORS, IT expertise - ITE, Top management support - TMS, Resources - RSC, IS department size - IDS, IT infrastructure - IIF, Formalization - FOR, Centralization - CEN Organizational readiness - ORE, Product champion - PCH

$\mathrm{S}$ - Significance : Significant - $\mathrm{P}$, Not significant $-\mathrm{N}, \quad$ CRV - Correlation values 